\title{
The summer circulation over the eastern Mediterranean and the Middle East: influence of the South Asian monsoon
}

\author{
Evangelos Tyrlis $\cdot$ Jos Lelieveld $\cdot$ Benedikt Steil
}

Received: 21 November 2011 / Accepted: 6 September 2012/Published online: 28 September 2012

(C) The Author(s) 2012. This article is published with open access at Springerlink.com

\begin{abstract}
The summer circulation over the eastern Mediterranean and the Middle East (EMME) is dominated by persistent northerly winds (Etesians) whose ventilating effect counteracts the adiabatic warming induced by large scale subsidence. The ERA40 dataset is used to study the vertical distribution of these circulation features, which both appear to be reconciled manifestations of the South Asian monsoon influence. As predicted by past idealized modeling studies, in late spring a westward expanding upper level warm structure and subsidence areas are associated with Rossby waves excited by the monsoon convection. Steep sloping isentropes that develop over the EMME facilitate further subsidence on the western and northern periphery of the warm structure, which is exposed to the midlatitude westerlies. The northerly flow and descent over the eastern Mediterranean have maxima in July that are strikingly synchronous to the monsoon convection over northern India, where the weaker easterly jet favors a stronger Rossby wave response and consequent impact on the EMME circulation. The pronounced EMME topography
\end{abstract}

\footnotetext{
E. Tyrlis $(\bowtie) \cdot J$. Lelieveld

Energy, Environment and Water Research Center,

The Cyprus Institute, 20 Konstantinou Kavafi Street,

2121 Nicosia, Cyprus

e-mail: e.tyrlis@cyi.ac.cy

J. Lelieveld · B. Steil

Max Planck Institute for Chemistry,

55020 Mainz, Germany

e-mail: jos.lelieveld@mpic.de

B. Steil

e-mail: benedikt.steil@mpic.de

J. Lelieveld

King Saud University, Riyadh 11451, Saudi Arabia
}

modifies the monsoon induced structure, firstly, by inducing orographically locked summer anticyclones. These enhance the mid and low level northwesterly flow at their eastern flanks, leading to distinct subsidence maxima over the eastern Mediterranean and Iran. Secondly, topography amplifies the subsidence and the northerly flow over the Aegean, Red Sea, the Iraq-Gulf region and to the east of the Caspian Sea.

Keywords Monsoon - Etesians - Mediterranean · Summer circulation - Rossby waves - Middle East . Subsidence

\section{Introduction}

During boreal summer, the northward retreat of the midlatitude zone of baroclinicity leaves the eastern Mediterranean and the Middle East (hereafter EMME, Fig. 1a) under the influence of the South Asian monsoon, of which the observed seasonal reversals in the atmospheric circulation and precipitation develop in response to the differential land-sea heating between the vast Asian continent and the surrounding Indian and Pacific Oceans (e.g. Trenberth et al. 2006; Yang and Lu 2006). Sensible heating (mainly over the Tibetan plateau), radiative and predominantly convective heat sources/sinks are the most important large-scale processes driving the summer Asian monsoon, which consists of distinctive subsystems including the regions with maxima of mean JJAS ascent and precipitation shown in Fig. 2: (a) Indian summer monsoon (ISM) covering the Arabian Sea, peninsular or continental India and the Bay of Bengal, (b) East Asian summer monsoon (EASM) covering northern China, Korea and Japan, and (c) western North Pacific summer monsoon (WNPSM) 
covering the South China and Philippine Seas (Wang et al. 2001; Ding and Sikka 2006).

As the massive monsoon heat low expands towards the Mediterranean through the formation of the Persian trough (Bitan and Saaroni 1992; Saaroni and Ziv 2000; Alpert et al. 2004; Saaroni et al. 2010), a sharp east-west pressure gradient builds up over the EMME resulting in persistent northerly winds (Fig. 1b), known in the Aegean Sea region as the Etesians (HMSO 1962; Metaxas 1977; Maheras 1980; Prezerakos 1984; Reddaway and Bigg 1996; Zecchetto and de Biasio 2007; Chronis et al. 2011). The ventilating effect of the Etesians counteracts the adiabatic warming induced by large scale subsidence especially over the central and eastern Mediterranean (Ziv et al. 2004), which inhibits cloud formation and convection, resulting in a prolonged summer dry period.

Although the existence of the subsidence zone is well documented by observational and modeling studies, the dynamics involved are the subject of debate. The formation of the major subtropical dry zones and deserts is traditionally attributed to the descending branch of the Hadley Cell that suppresses convective activity (Charney 1975), see also Rodwell and Hoskins (1996) for a discussion. However, this mechanism should not be used indiscriminately to explain the dryness over the eastern Mediterranean (hereafter EMED) during summer when the descending branch of the zonal mean Northern Hemisphere Hadley Cell weakens (Rodwell and Hoskins 1996).

(a) TOPOGRAPHY

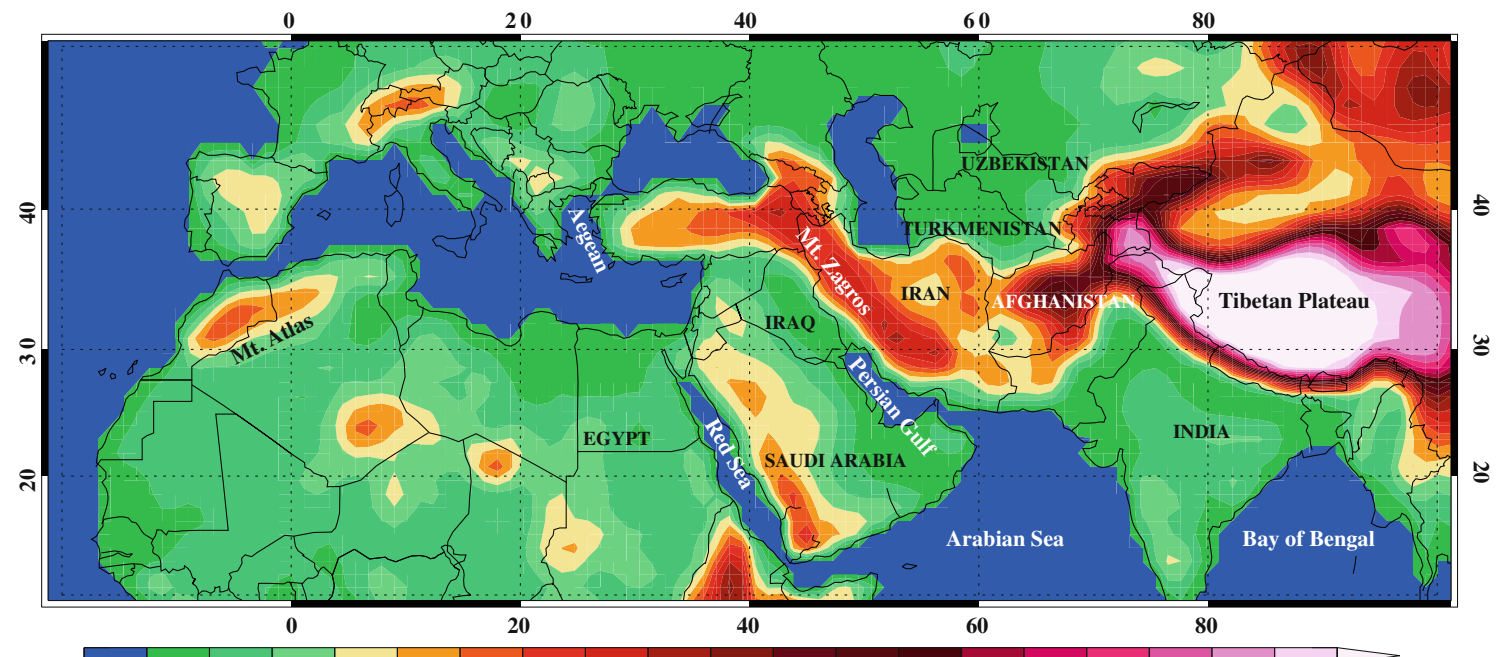

$\begin{array}{llllllllllllllllllll}0 & 250 & 500 & 750 & 1000 & 1250 & 1500 & 1750 & 2000 & 2250 & 2500 & 2750 & 3000 & 3250 & 3500 & 3750 & 4000 & 4250 & 4500 & 4750\end{array}$ (metres)

(b) JULY MSLP, $1000 \mathrm{hPa}$ WIND

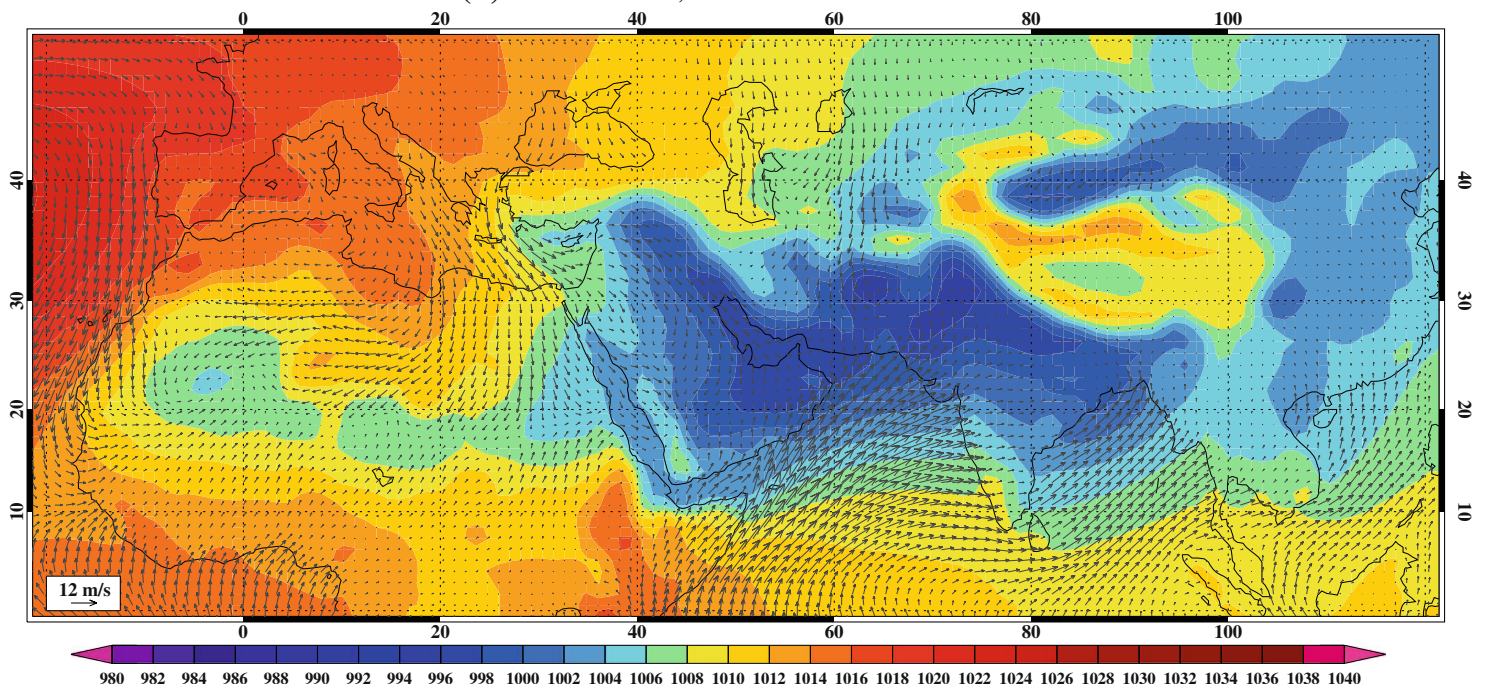

Fig. 1 Altitude (a) and July climatology of MSLP and 1,000 hPa horizontal wind (b) 
(a) JJAS PRECIPITATION

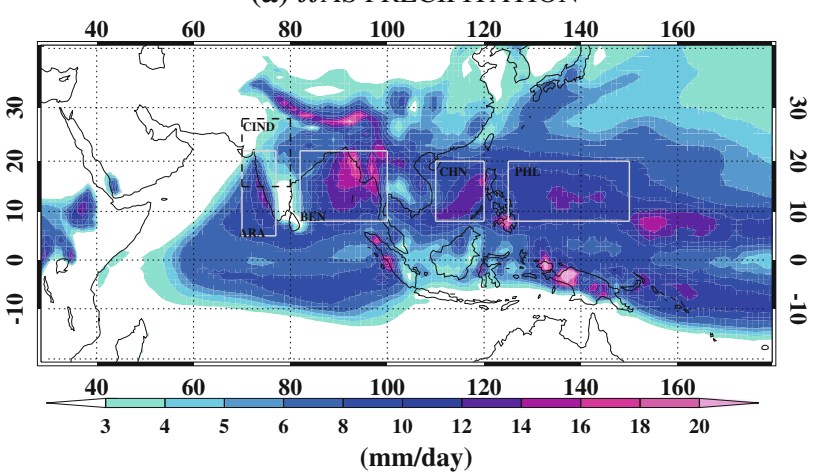

(b) JJAS $500 \mathrm{hPa}$ OMEGA

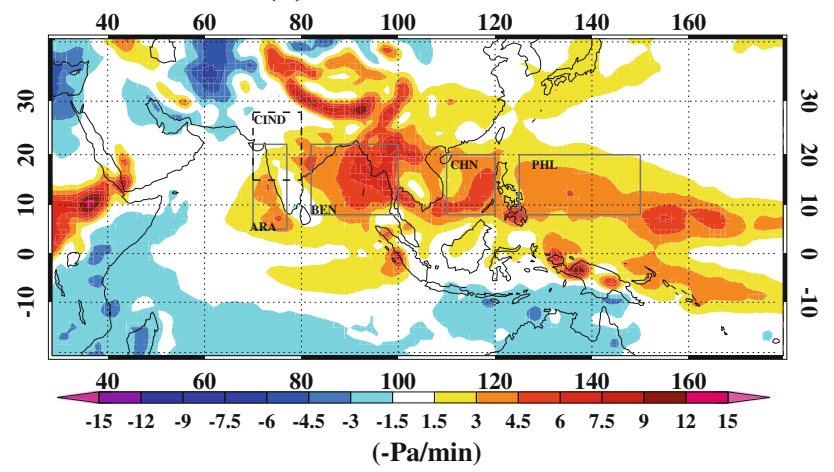

Fig. 2 a Daily mean JJAS precipitation (mm/day). b JJAS climate of $500 \mathrm{hPa}$ omega $(-\mathrm{Pa} / \mathrm{min})$. Blue (red) colors denote subsidence (ascent). Regional monsoon intensity indices are defined over the illustrated box areas

Further, the zonal mean representation of the Hadley Cell can be misleading, as first noted by Schulman (1973), because the summer regional monsoon induces a reverse meridional circulation, which suggests a very weak global mean descending branch of the Hadley Cell, masking the local Hadley Cell circulation over the EMME sector (Ziv et al. 2004). Goswami et al. (1999) presented evidence of a distinct Hadley Circulation signature specifically over eastern North Africa, connecting the EMME to the eastern Sahel monsoon system. The observed asymmetry of the Hadley circulation with the disproportionately stronger descending branch was attributed to the additional influence of a monsoon driven zonal circulation.

Subsequently, a 'Walker type' closed circuit (Webster 1994) was proposed, with vigorous ascending motion in South Asia, continuous westward flow and large scale subsidence over the EMME ( $\mathrm{Ziv}$ et al. 2004). Such a closed overturning circulation was not identified by the trajectory analysis of Rodwell and Hoskins (1996), revealing that the bulk of the air subsiding over the EMME has a midlatitude origin. Based on idealized simulations and sensitivity tests with a primitive equation model, they proposed that the Asian monsoon heating induces an equatorially trapped Rossby wave to its west, with a warm structure at its core. The interaction of this structure with the midlatitude westerlies triggers subsidence over the Mediterranean, whereas the orography focuses the flow and hence the subsidence over specific areas. In addition to the remote monsoon forcing, a large portion of the Mediterranean subsidence is attributed to the local 'diabatic enhancement' mechanism through which adiabatic descent leads to radiative cooling under clear sky conditions, furthering diabatic descent (Rodwell and Hoskins 1996, 2001).

The Etesians can actually be seen as the equatorward flow that forms below the subsidence region induced by the westward propagating Rossby wave, in agreement with Sverdrup balance (Rodwell and Hoskins 2001). Thus, both the EMME subsidence and the Etesians are interconnected manifestations of the remote monsoon forcing. The Etesians control many aspects of the EMME climate and atmosphere, including reduced air quality during summer in the region due to the transport of pollutants from the eastern European industrial zones (Lelieveld et al. 2002; Kalabokas et al. 2008) and biomass burning (Sciare et al. 2003). More details with respect to the influence of the Etesians in the region and a climatology of the phenomenon will be presented in Tyrlis and Lelieveld (in preparation).

Beyond the role of the Mediterranean as a 'passive' receiver of the monsoon signal, the Etesians act as a 'transmitter' towards the Sahel monsoon system (Raicich et al. 2003) by regulating the southward moisture transport (Lelieveld et al. 2002; Rowell 2003; Jung et al. 2006), and thus linking the two major global monsoon systems. Given the aforementioned local and remote effects of the Mediterranean circulation and its teleconnections, the development of indices describing the EMME circulation would be beneficial for the understanding of the present and future climate of the region, which is projected to be a climate change 'hot spot' (Giorgi 2006; Lelieveld et al. 2012).

In the next section, the data and the methodology applied in this study for the construction of the relevant indices are described. Further, the approximations made for the calculation of the thermodynamic energy equation terms are outlined. Quantification of these terms is expected to be an important tool for identifying the individual dynamical processes resulting in the thermodynamic state of the troposphere over the region. Section 3 aims at a detailed description of the summer EMME circulation throughout the depth of the troposphere. In Sect. 4 evidence is presented concerning the large scale influence of the South Asian monsoon in setting the scene over the EMME. In Sect. 5 the effect of the EMME topography on the low and mid level circulations is discussed. The last section summarizes the results and presents conclusions. 


\section{Data and methodology}

\subsection{Data description}

In this study, data is derived from the ECMWF ERA-40 dataset (Uppala et al. 2005). Six-hourly analyses of mean sea level pressure (MSLP), precipitation, temperature and wind components are used, which are available on a N80 full-Gaussian grid $\left(\sim 1.1^{\circ} \times 1.1^{\circ}\right)$ and on pressure levels spanning the depth of the troposphere. Apart from analysis variables, ECMWF model forecasts for temperature, wind and diabatic heating are used for the quantification of the thermodynamic energy equation terms (see Sect. 2.3). Effectively, in our analysis 45 summer periods were included from 1958 to 2002.

\subsection{Definition of indices}

The primary aim of this work is the investigation of the link between the summer Asian monsoon and EMME circulation through study of the synchronicity of the detailed seasonal cycles of EMME circulation and monsoon activity, which is expected to shed light on the dynamical processes governing their connection. Commonly used monthly or seasonally mean indices may not be adequate for addressing the causality between the two phenomena on intraseasonal timescales and this need dictates the construction of daily metrics describing the monsoon intensity and EMME circulation. Given the small zonal component of the northerlies over the EMED (Fig. 3a), the intensity of the Etesians is represented by the spatial average of the $850 \mathrm{hPa}$ meridional wind component over the box area depicted in Fig. 3b (see Table 1 in the "Appendix"), while a measure of the EMED subsidence is obtained by the spatial average of 500/200 hPa omega vertical velocity over the aforementioned box area. For the choice of a monsoon index, precipitation and $500 / 200 \mathrm{hPa}$ omega are spatially averaged over the areas delineated in Fig. 2 to obtain daily regional monsoon intensity indices representing the main four regions of activity of the ISM and WNPSM monsoon subsystems. Note that the coordinates of the main areas corresponding to eastern Arabia (ARA), Bay of Bengal (BEN), South China Sea (CHN), Philippines Sea (PHL) and their northern/ southern subregions, as well as the areas equatorwards of the main domains, are listed in Table 1. Table 2 lists the abbreviations used throughout this study (see "Appendix"). The temporal averaging of all the relevant 6-hourly incremented variables over calendar days results in less noisy daily timeseries of the EMED northerly flow and subsidence indices, as well as the regional monsoon metrics. Finally, seasonal cycles of all indices featuring daily resolution are constructed allowing the study of the seasonal pace of the regional monsoon activity.
The development of daily regional monsoon indices based on gridded omega and precipitation data follows the use of a plethora of seasonally averaged convective (Wang and Fan 1999) and precipitation indices (Goswami et al. 1999) defined over various subdomains across South Asia, and they are based on the principle that strong summer precipitation in the area (Fig. 2a), the intense mid and upper level ascending motion (Fig. 2b) and even the negative anomalies in the outgoing long-wave radiation (Lin 2009) are characteristic monsoon manifestations identified by the corresponding indices. Indeed our monsoon index based on omega acquires maxima in areas of monsoon convection (vigorous ascent) where the precipitation based monsoon indices also feature maxima. This is evident even from the seasonal mean fields of Fig. 2, but also from the high correlation between the daily omega and precipitation based monsoon index timeseries (not shown). Frequently, circulation indices (Webster and Yang 1992; Goswami et al. 1999; Wang et al. 2009) are employed as monsoon intensity metrics, which incorporate information about the wind shear between the 850 and $200 \mathrm{hPa}$ levels (Fig. 3a, c). Although they benefit from the use of A-type variables, such as $200 / 850$ winds, which are directly influenced by observations (Wang and Fan 1999), their more universal nature and definition over a large domain could hinder our effort to assess the impact of fine scale regional monsoon activity on the EMME. Thus, the use of regional indices based on spatially averaged omega and precipitation provides a simple and flexible methodology for the study of the remote influence, not only of the discrete monsoon subsystems (see Sect. 1) which are relatively independent (Wang and Fan 1999), but also the influence of convective activity occurring over smaller regions, such as the core continental India (CIND, see Table 1). The high correlation (above 0.7) between the interannual variability of the traditional metric of the Indian summer monsoon, known as the All India summer monsoon rainfall index, based on area weighted continental India station rainfall data ${ }^{1}$ (Parthasarathy et al. 1992, 1994), and that of total JJAS precipitation (based on ERA40 gridded data) averaged over continental India, implies that the above described methodology provides reliable measures of regional monsoon intensity.

\subsection{Description of the thermodynamic state of the troposphere}

The investigation of the monsoon induced impact on the thermodynamic state of the troposphere over the EMME is facilitated by the quantification of the terms of the

\footnotetext{
${ }^{1}$ Whole India precipitation data downloaded from $\mathrm{ftp}: / / \mathrm{www}$. tropmet.res.in/pub/data.
} 
Fig. 3 Mean July omega $(-\mathrm{Pa} / \mathrm{min})$ and horizontal wind at $850 \mathrm{hPa}(\mathbf{a}), 500 \mathrm{hPa}(\mathbf{b})$ and $200 \mathrm{hPa}$ (c). Blue (red) colors denote subsidence (ascent). The white box marks the boundaries of the EMED region $\left(17-31^{\circ} \mathrm{E}\right.$ and $30-41^{\circ} \mathrm{N}$ )

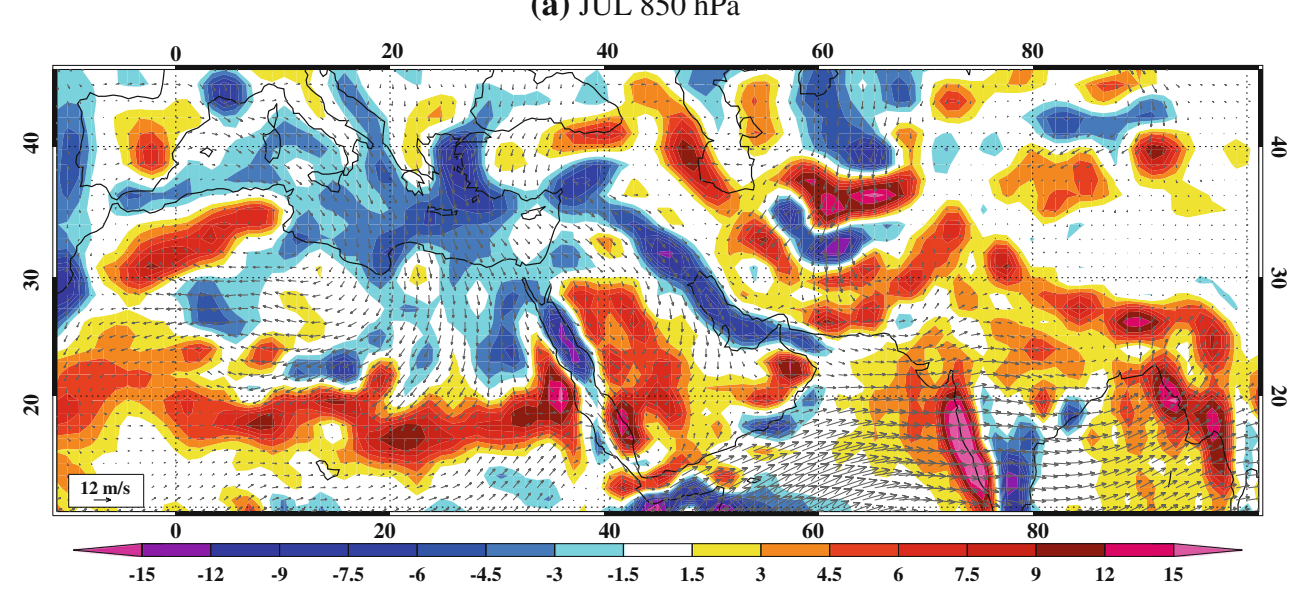

(b) JUL $500 \mathrm{hPa}$

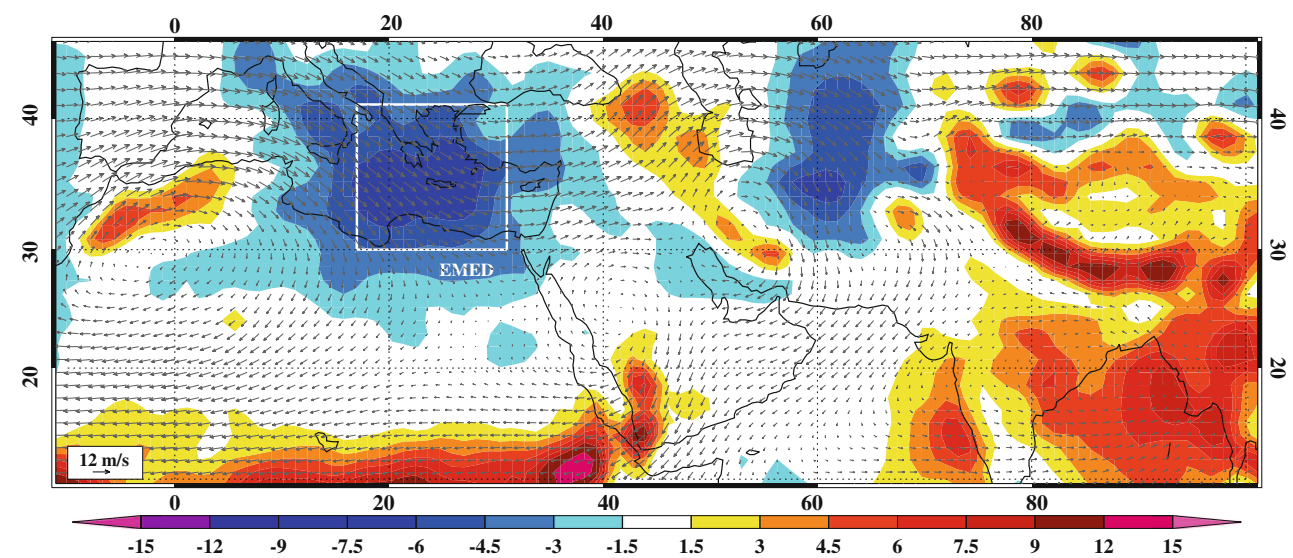

(c) JUL $200 \mathrm{hPa}$

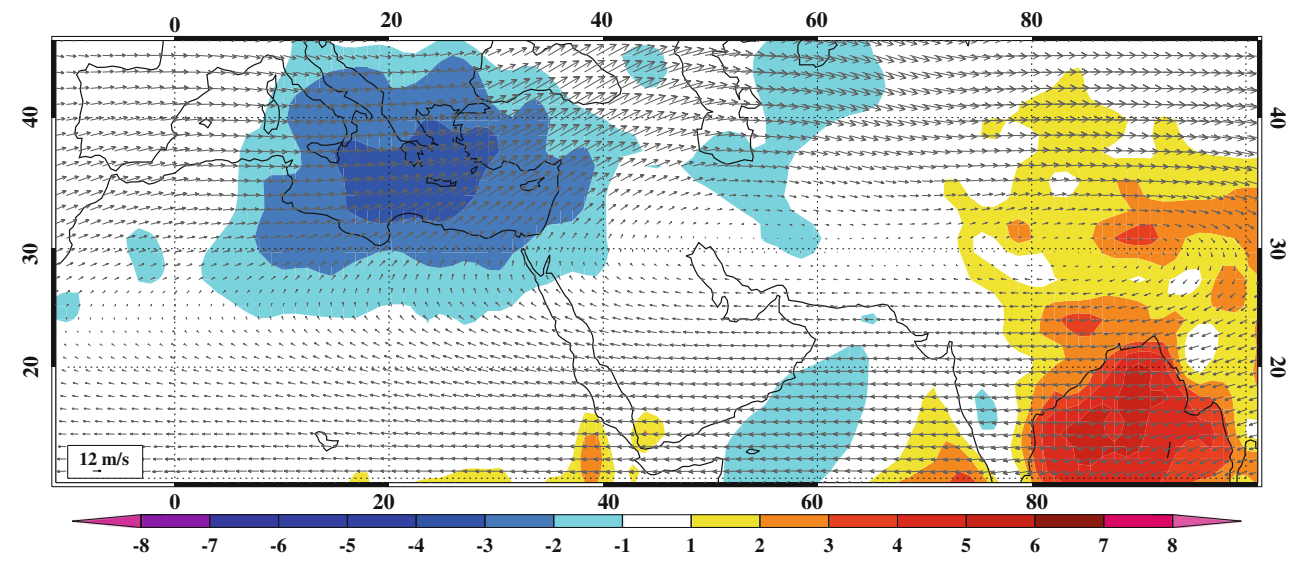

thermodynamic energy equation, which can be written in isobaric coordinates (Holton 1992) as follows

$$
\underbrace{\frac{\partial T}{\partial t}}_{\text {LTT }}=\underbrace{\frac{J}{C_{p}}}_{\text {TPTT }}-\underbrace{\frac{T}{\theta} \frac{\partial \theta}{\partial p} \omega}_{\text {VATT }}+\underbrace{\left(-u \frac{\partial T}{\partial x}\right)}_{\text {ZATT }}+\underbrace{\left(-v \frac{\partial T}{\partial y}\right)}_{\text {MATT }}
$$

where $\mathrm{T}$ is temperature, $\theta$ is potential temperature, $\mathrm{u}$ and $\mathrm{v}$ are the horizontal wind components, $\omega$ is the vertical velocity (omega), $\mathrm{J}$ is the diabatic heating rate and $C_{p}$ is the specific heat of dry air at constant pressure. The term $\frac{\partial T}{\partial t}$ corresponds to the Local Temperature Tendency (LTT), $\frac{J}{C_{p}}$ represents the total physics temperature tendency (TPTT), 
$-\frac{T}{\theta} \frac{\partial \theta}{\partial p} \omega$ gives the temperature tendency due to Vertical Advection (VATT), whereas the terms $-u \frac{\partial T}{\partial x}$ and $-v \frac{\partial T}{\partial y}$ represent the temperature tendency due to zonal advection (ZATT) and meridional advection (MATT), respectively. The sum of the terms ZATT and MATT corresponds to the total temperature changes caused by horizontal advection (HATT). Both HATT and VATT represent temperature tendencies due to adiabatic processes, whereas TPTT corresponds to the diabatic heating term. Thus, Eq. 1 gives the local total temperature change as a result of diabatic and adiabatic processes.

Since TPTT is available from the ECMWF model only as net temperature tendency from parameterized processes (accumulated over the model $6 \mathrm{~h}$ forecast period), all the remaining terms are also calculated from 6-hourly forecasts of temperature and wind components to acquire maximum consistency. The diabatic heating term includes warming/cooling due to radiative processes, latent heat exchanges and diffusive/turbulent heat transport. In the ECMWF model forecasts, the total diabatic heating (i.e. TPTT) and only the temperature tendency due to radiation are stored. The latter term could be further split into the clear-sky and cloud contributions, with a further separation of the clear-sky radiative tendency into short and long wave components (Fueglistaler et al. 2009).

Six-hourly forecasts from the ECMWF model, which are available on the Gaussian grid and on 23 fixed pressure levels in the range 1,000-1 $\mathrm{hPa}$, are used for the calculation of the individual terms of Eq. 1. All terms are also calculated at increments of $6 \mathrm{~h}$. For the terms ZATT, MATT and VATT, temperature and wind components are averaged during the previous period of $6 \mathrm{~h}$. Horizontal and vertical temperature derivatives are calculated as the central differences with respect the two neighboring grid points in the corresponding horizontal or vertical direction. At each grid point the daily values of LTT and TPTT (expressed in K/day) are calculated as the sum of the 6-hourly temperature tendencies and accumulated 6-hourly TPTT, respectively, for the periods ending at 06,12,18 and 00 UTC. Daily values of the remaining terms are calculated as the average of the 6-hourly incremented values again at $06,12,18$ and 00 UTC of the corresponding day. The complete daily timeseries of each term spans the period 1 January 1958-31 August 2002. The unbalanced representation of the more instantaneous advection terms compared to the temperature tendency terms in Eq. 1 is partially responsible for the lack of equation budget closure at each time step. Here the averaging of temperature and wind over the period during which the TPTT is accumulated in the model simulation, and the calculation of daily averages gives more accurate correspondence.

\section{General EMME circulation features}

Insight into the summer EMME circulation is gained by investigating the vertical cross sections shown in Fig. 4. The latitude-pressure (a, c) and longitude-pressure profiles (b, d) depict mean July omega and $\theta$ averaged over longitude and latitude sectors cutting through the main regions of ascent and subsidence shown in Fig. 3. The thick line marks the 2 PVU (potential vorticity unit) surface, which corresponds to the dynamical tropopause (Hoskins 1997). Here, July climatologies are presented corresponding to the maximum monsoon activity and its stronger midlatitude impact (see Sect. 4). For the remainder of the traditional June-September monsoon period and away from the core monsoon activity, climatologies are similar but with gradually decreasing amplitudes (not shown).

In the framework of PV-thinking (Hoskins et al. 1985; Hoskins 1991), the lifted tropopause over the tropics and the South Asian monsoon region could be seen as the result of potential vorticity (PV) destruction and the formation of an upper level negative PV anomaly above the corresponding diabatic heating sources. Reduced (enhanced) stratification is observed within (above-below) the PV anomaly. Due to the stratification anomalies induced by the tropical convective activity, sloping isentropes prevail in the meridional profiles, especially within the latitude band $30-45^{\circ} \mathrm{N}$, marking the sharp meridional temperature gradient between the tropics and the polar regions, with the slope of the isentropes reversing above $200 \mathrm{hPa}$. In the zonal profiles, the monsoon induced stratification anomaly is responsible for the east-west slope of the isentropes, which is more evident along $32-40^{\circ} \mathrm{N}$, away from the zonally symmetric tropical influence, where the zonally asymmetric monsoon structure emerges (Fig. 4b).

The narrow band of ascent over the tropics marks the Intertropical Convergence Zone and the ascending branch of the Hadley Cell, which is located at northern latitudes over Africa, delineating the Sahel region, though interrupted over the Horn of Africa and the western Arabian Sea (Fig. 3b). Widespread monsoon induced ascent is observed to the east of $70^{\circ} \mathrm{E}$, which is deepest over the Bay of Bengal. Overall, the most prominent subsidence zones coincide with the areas where the isentropes slope steeply so that even a small horizontal motion can be associated with a large vertical displacement. An envelope area of subsidence extends from the central Mediterranean until Iran, marking the full extent of the east-west slope of isentropes (Fig. 4b). Subsidence is stronger and extends throughout the tropospheric column over the central and eastern Mediterranean, with a maximum in the vicinity of Crete and around $500 \mathrm{hPa}$ where the slope is steepest (Fig. 4a). Subsidence occurs as air masses converge at upper levels and diverge at lower levels, while fanning out 
(a) JUL OMEGA $24-28^{\circ} \mathrm{E}$

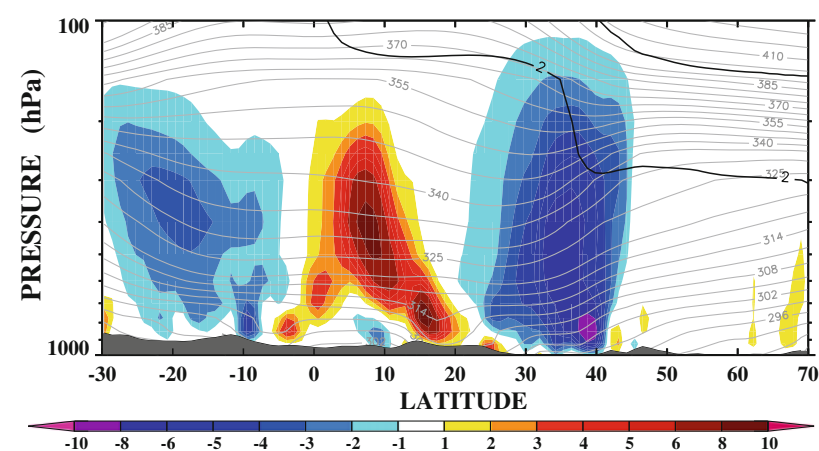

(b) JUL OMEGA $32-40^{\circ} \mathrm{N}$

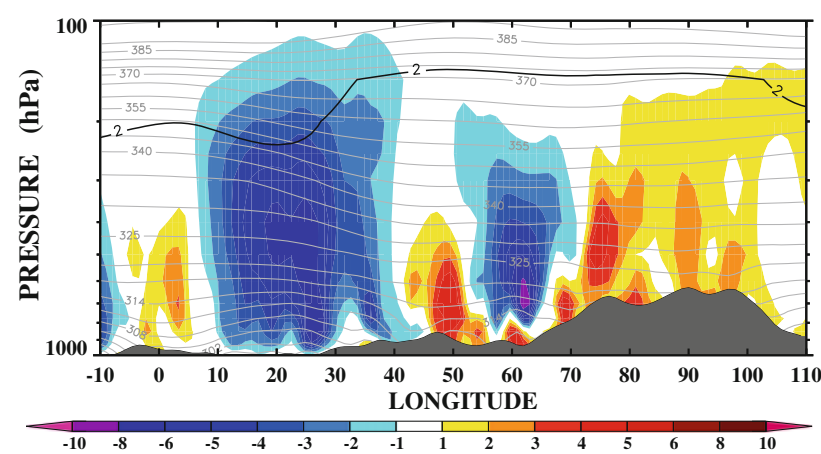

(c) JUL OMEGA $55-65^{\circ} \mathrm{E}$

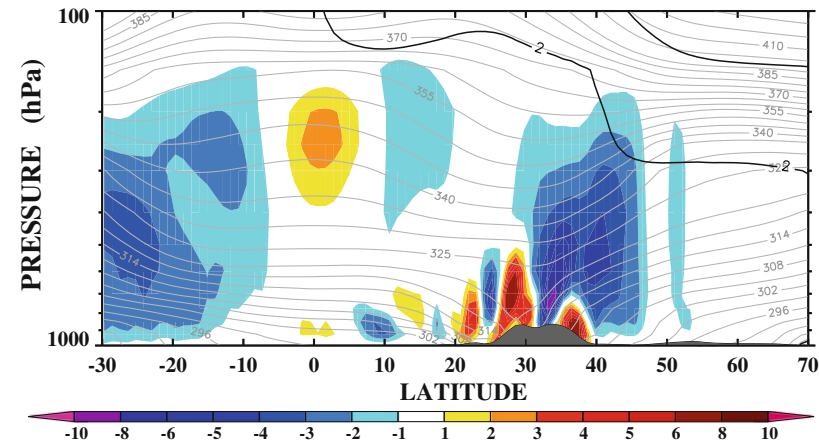

(d) JUL OMEGA $21-26^{\circ} \mathrm{N}$

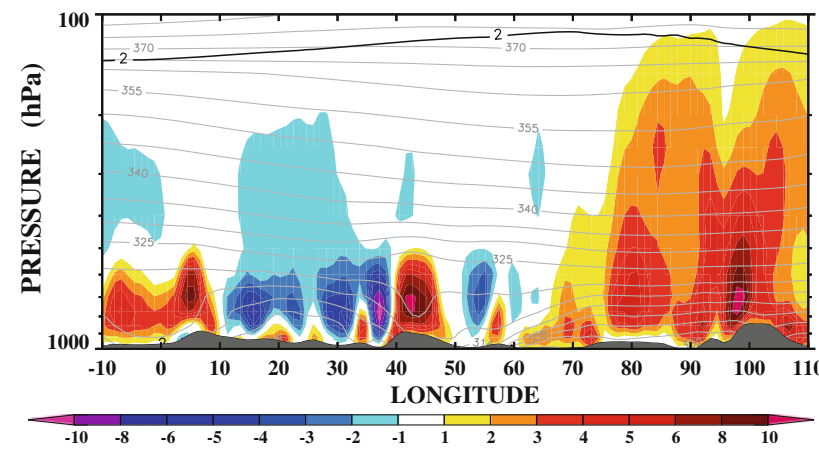

Fig. 4 Pressure-latitude profiles of mean July omega (filled contours in $-\mathrm{Pa} / \mathrm{min}$ ) and $\theta$ (contours in $\mathrm{K}$ ) averaged over the Aegean Sea (a) and Iran (c). Pressure-longitude profiles of mean July omega and $\theta$ averaged over the latitude bands of the Mediterranean (b) and central Saudi Arabia-northern ISM region (d). Blue (red) colors denote subsidence (ascent). The thick line marks the dynamical tropopause. Orography is superimposed southwards to form the low level cyclonic flow around the massive monsoon low. This flow is modified by topography so that the northerly winds across the EMME are funnelled and accelerated through (i) the Aegean Sea, (ii) the Red Sea Straits and (iii) the Iraq-Persian Gulf regions (Fig. 3a). Its westernmost portion reaches the Sahel region whereas its easternmost branch eventually reaches the Indian Ocean. A distinct low level intense subsidence core lies over the Aegean (Fig. 4a), which underlines the importance of topographic influence, to be discussed in Sect. 5. Strong low and mid level subsidence is also apparent over areas (ii) and (iii). A second area of intense, mainly mid level subsidence, is evident to the east of the Caspian Sea over Iran, Turkmenistan and Afghanistan, hereafter referred to as Iran for simplicity, (Figs. 3b, 4b), also accompanied by an 'Etesians-like' northerly flow in the low and mid troposphere, accelerating in the narrow passage between the Iranian and Tibetan plateaus. The air masses are forced to recurrent ascent and subsidence due to the pronounced topography in the region featuring successive mountain ranges and valleys.

\section{Monsoon influence over the EMME}

\subsection{Synchronicity of monsoon onset and EMED subsidence}

In this section, we describe the role played by the seasonal evolution of the monsoon influence on the summer climate of the EMME region. During boreal winter, subsidence associated with the descending branch of the Hadley Cell extends over the latitude band $15-30^{\circ} \mathrm{N}$ (Fig. 5a), which is also evident in the mean February latitudinal distribution of the zonally averaged $500 \mathrm{hPa}$ omega depicted in Fig. 5c (black line). On average the subsidence maxima are located over northwest-northeast Africa, the northern parts of the Arabian Sea and the Bay of Bengal. Following the seasonal cycle of solar declination, the Hadley Cell structure and its descending branches migrate to the north during boreal summer. Subsidence is always stronger in the winter Hemisphere. The weakening of the zonal mean subsidence in the Northern Hemisphere during boreal summer is larger compared to the weakening observed in the Southern Hemisphere during austral summer, due to the opposing monsoon related ascent observed for latitudes up to $40^{\circ} \mathrm{N}$ (Fig. 3b). Concerning the proposed 'Walker type' circulation connecting the ascent and descent regions (see Sect. 1), note the southern position of the monsoon ascent compared to the Mediterranean and Iran subsidence regions, which indicates that the observed circulation is actually characterized by a meridional tilt (Fig. 3c). In any case, the anomalous intensity, with some of the highest 
(a) FEBRUARY

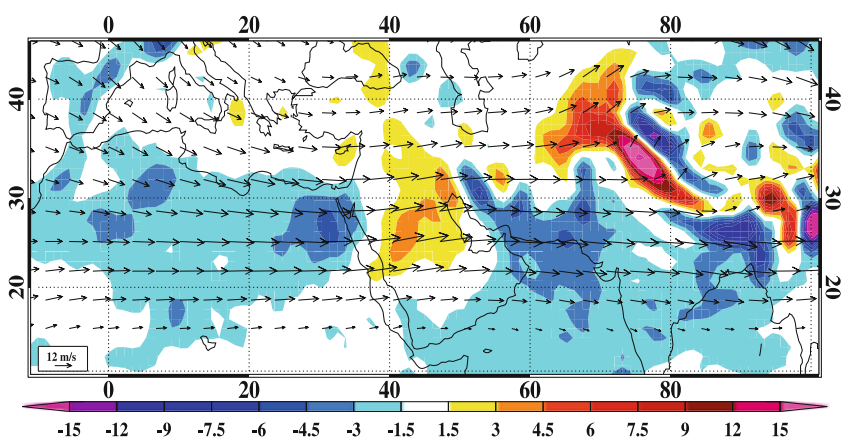

(c) ZONAL MEAN

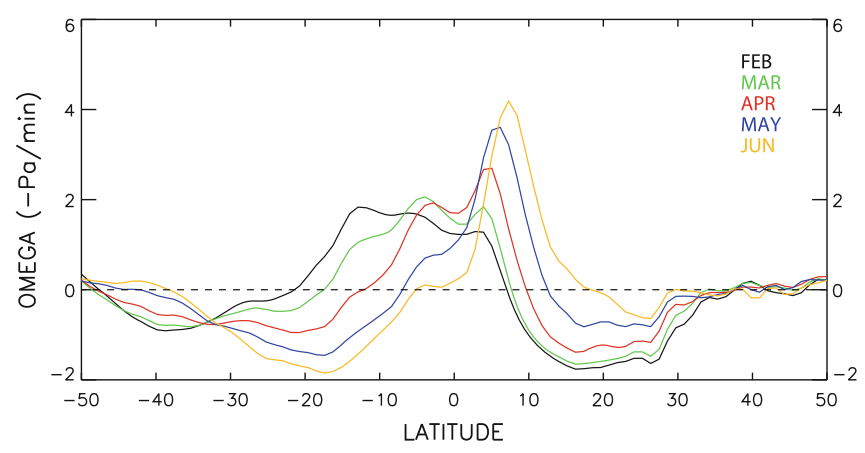

Fig. 5 Evolution of monthly mean $500 \mathrm{hPa}$ omega $(-\mathrm{Pa} / \mathrm{min})$ and horizontal wind for February (a) and March (b). Blue (red) colors denote subsidence (ascent). February-June evolution of the latitudinal

subsidence values observed in the free troposphere globally, and the relatively high latitude of the summer subsidence over the eastern Mediterranean (Fig. 5d) and Iran (not shown), represent striking deviations from the zonal mean and its seasonal pace (and even from neighboring regions such as the western Mediterranean) that cannot be attributed to the Hadley Circulation alone. Note that during July, mid level subsidence reaches $0.07 \mathrm{hPa} / \mathrm{min}$ over the eastern Mediterranean and Iran regions, while further below $(850 \mathrm{hPa})$, it exceeds $0.1 \mathrm{hPa} / \mathrm{min}$ locally over the Aegean Sea, the Red Sea and the Persian Gulf regions. Subsidence for any given summer day can be significantly stronger.

The weakening tendency of the subsidence over the subtropics starting in March, which is attributed to global drivers and is visible from the breakdown of the zonally uniform subsidence zone over the subtropics (Fig. 5b), is abruptly reversed after April only over the EMED (Fig. 5d) and over Iran, but not over the western Mediterranean (not shown). In May, as subsidence intensifies over Egypt and the northern Arabian Sea and both centers rapidly shift towards their summer positions over Crete and Iran, a third area of subsidence develops over the Persian Gulf, which weakens in June-July as it expands to the northwest across Iraq (Fig. 3b). The reverse migration occurs in autumn (b) MARCH

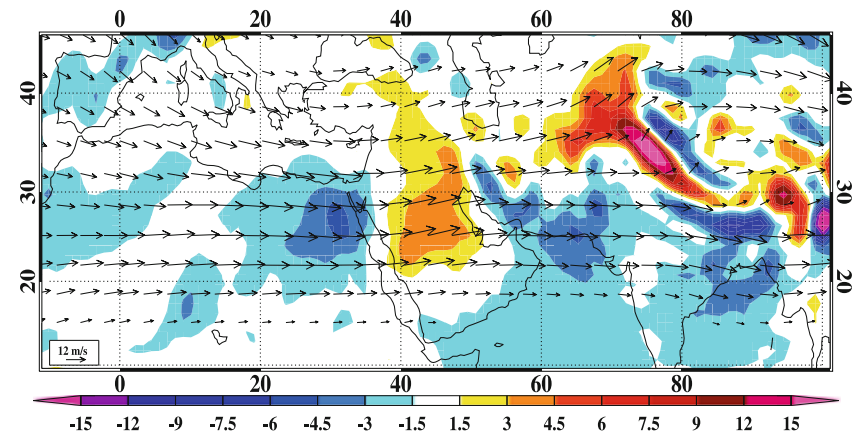

(d) $15-35^{\circ} \mathrm{E}$

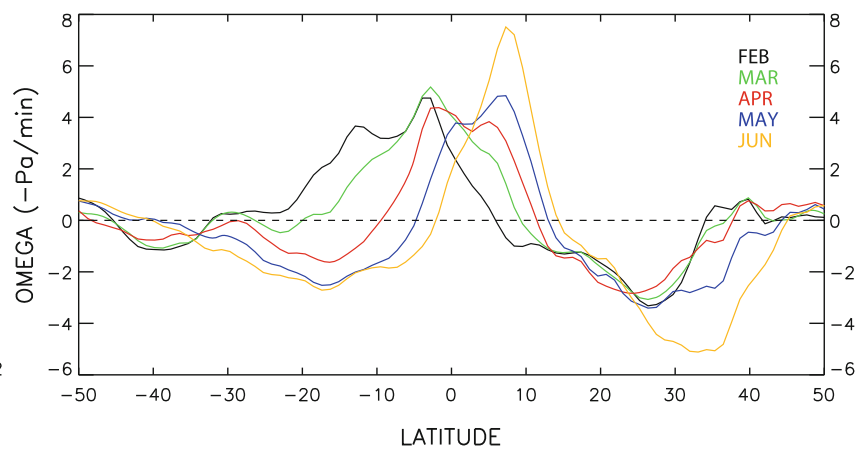

distribution of monthly mean $500 \mathrm{hPa}$ omega $(-\mathrm{Pa} / \mathrm{min})$ averaged zonally (c) and within the sector $15-35^{\circ} \mathrm{E}$, over the eastern Mediterranean (d)

with the subsidence zones withdrawing towards their winter positions.

Figure 6a (grey curve) illustrates the seasonal development of the $850 \mathrm{hPa}$ meridional wind averaged over the EMED region, which serves as a northerly flow proxy, given that the zonal component of the flow is very small. It also depicts the seasonal pace of $500 \mathrm{hPa}$ omega averaged over the EMED and the five areas depicted in Fig. 2, which represent the regional monsoon intensity of the ISM and WNPSM subsystems (a), and furthermore over the northern (b), southern (c) and equatorial (d) subdomains listed in Table 1 . The profiles for $200 \mathrm{hPa}$ vertical velocity, representing upper level subsidence over the Mediterranean, and deep monsoon convection are qualitatively similar (not shown). All seasonal cycles are smoothed with an 11-day running average to produce less noisy profiles.

To facilitate the interpretations of the results depicted in Fig. 6, it is necessary to describe the seasonal evolution of the spatial distribution of monsoon activity across South Asia. The rainy season in the Indian Ocean region begins at the northern tip of Sumatra in early April and expands over the Bay of Bengal in May. In mid May the northwestern boundary of the massive convective activity cuts diagonally across the Bay of Bengal in the southwest-northeast 
direction. Soon afterwards, the convection spreads northwards and reaches the northeast coast of India around 10 June (Wang 1994; Wang and Fan 1999). The evolution of the ISM features also a second route over the Arabian Sea with northward progressing convection that reaches the southern tip of India (Kerala) around 1 June (Zhang et al. 2002; Wang and LinHo 2002; Pai and Nair 2009). Essentially, the CIND region, which includes a part of the northern Arabian Sea, is important because it marks the region where convection converges around 20 June (Wang and Fan 1999; Wang and LinHo 2002) and the 'terminal' destination of the northwestward advance of convection penetrating towards higher latitudes.

Simultaneously with this westward branch, in late April there is a bifurcation of convective activity through Malaysia-Thailand towards the South China and Philippines Seas. Convective activity is also very strong over the Philippines Sea and comparable with that over the Bay of Bengal, but its maximum is acquired almost a month later in mid August (Fig. 6a). Investigation of the day to day seasonal progression of precipitation/omega (not shown) reveals that convection over the South China Sea has a 'hybrid' character with an early outbreak in May and early June, especially off the coast of China (Fig. 6b, c). The convective activity crosses the sector simultaneously with that in the ISM region, reaching southern Japan in midJune and arriving in northern China in late July as part of the EASM subsystem (Zhang et al. 2002). After a less active spell in July, the main maximum occurs in August especially over its eastern parts, simultaneously with the activity to the east over the Philippine Sea, in association with the WNPSM subsystem.

In line with the sequence of mean monthly omega presented in Fig. 5, the northerly flow and large scale mid and upper level subsidence over the EMED begin near the end of April when the high frequency variability related to midlatitude winter synoptic activity weakens and is gradually replaced by the less variable summer regime. The Etesians and EMED subsidence intensify slowly until late May and subsequently at a much higher rate to reach their maxima during the first week of July. The weakening starts at a very slow pace until early September and then accelerates until late October, returning to its winter regime. The synchronicity of the seasonal advance of the EMED circulation and that of the ISM monsoon activity is striking (Fig. 6a). More specifically, there is remarkable timing between the deep convection onset over the southeastern parts of the Bay of Bengal and that of EMED subsidence/ northerly flow in late April. Although the onset over the Bay of Bengal and the Arabian Sea is rather sudden, the really deep EMED subsidence/northerly flow only starts when convection rapidly intensifies over the CIND area and the northern Arabian Sea (NARA). In addition to the onset timing, the strongest EMED subsidence occurs (a) TOTAL AREA

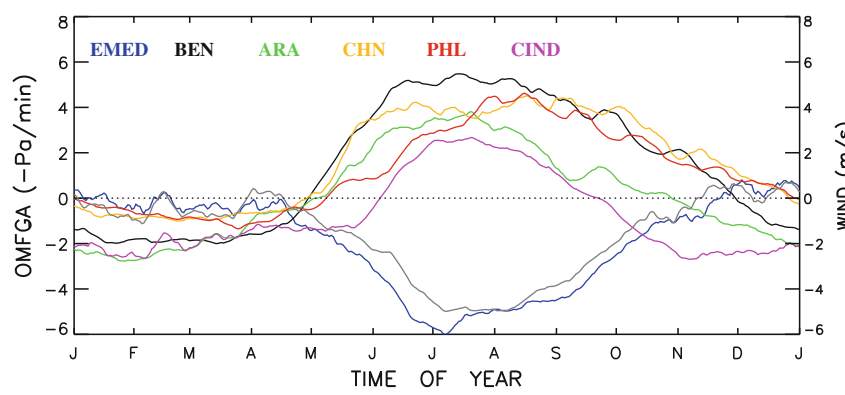

(c) SOUTH

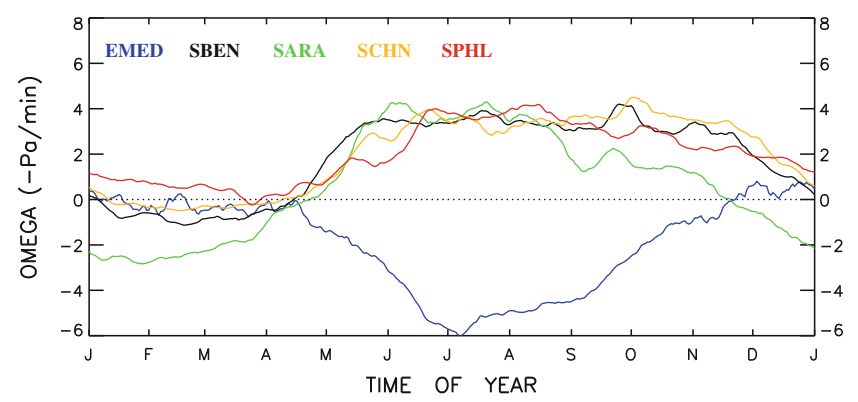

Fig. 6 Seasonal evolution of $850 \mathrm{hPa}$ meridional wind (grey line in a only, scaled on the right hand side vertical axis) and $500 \mathrm{hPa}$ omega $(-\mathrm{Pa} / \mathrm{min})$ averaged over the EMED and the monsoon

\section{(b) NORTH}

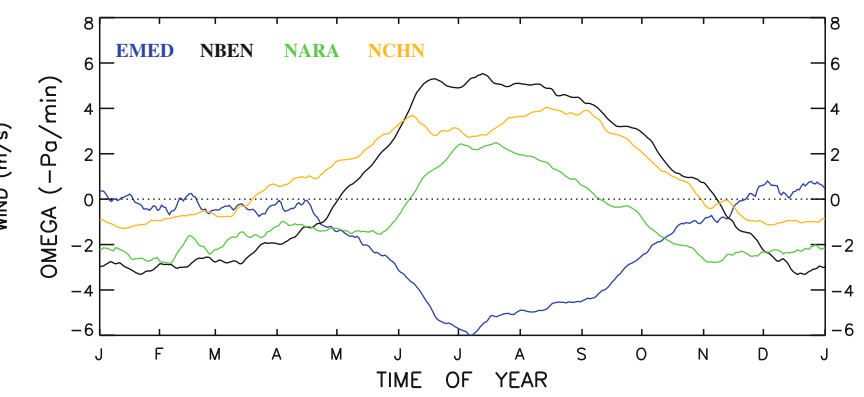

(d) EQUATOR

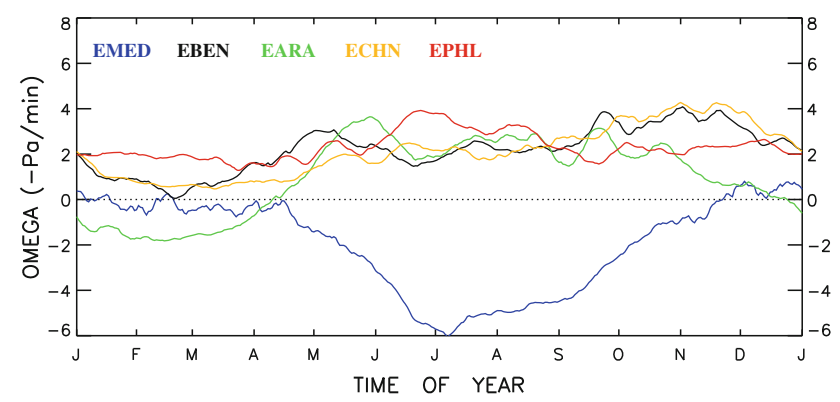

subregions depicted in Fig. 2 (a), as well as the northern (b), southern (c) and equatorial (d) subdomains listed in Table 1. Negative values for wind denote northerly flow and for omega represent subsidence 
(a) PREC

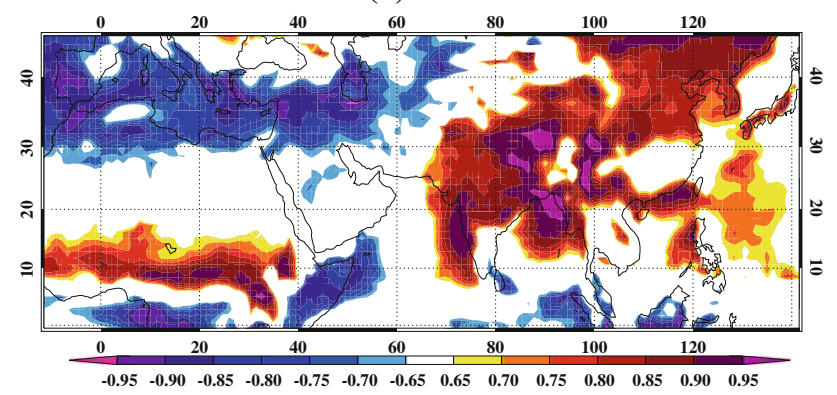

(b) $500 \mathrm{hPa}$ OMEGA

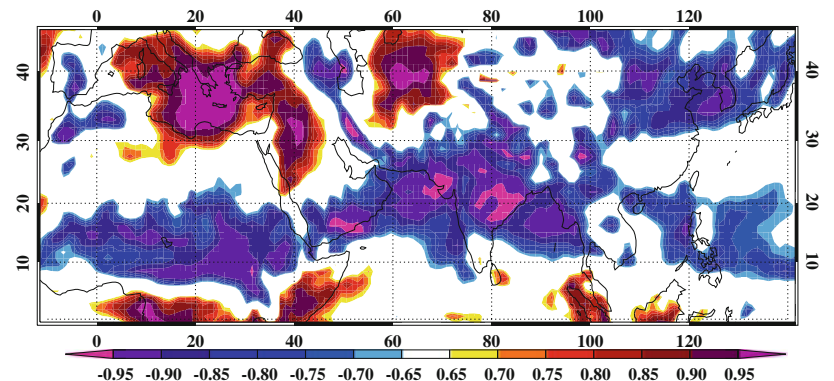

Fig. 7 Correlation coefficients of the summer seasonal cycle of $500 \mathrm{hPa}$ omega averaged over the EMED with the summer seasonal cycle of precipitation (a) and $500 \mathrm{hPa}$ omega (b)

simultaneously with the CIND and NARA convection maxima (Fig. 6a, b), while the synchronicity is closer to the northern rather than the southern parts of the Bay of Bengal and the South China Sea (Fig. 6b, c) and diminishes with respect to the convective activity in the equatorial region (Fig. 6d). Similarly, the weakening of the EMED circulation in September is synchronous with the waning of convection over the CIND, NARA and NBEN regions. From October onwards, in contrast with the weakening of the ISM activity, convection over the SBEN, SCHN and the PHL subdomains continues, which implies a weaker link of the EMED northerly flow and subsidence with the WNPSM activity.

The correlation coefficient between the seasonal evolution of the $500 \mathrm{hPa}$ omega averaged in the EMED (blue line Fig. 6) and that of precipitation or $500 \mathrm{hPa}$ vertical velocity is depicted in Fig. 7. The patterns at $200 \mathrm{hPa}$ are qualitatively similar to $500 \mathrm{hPa}$ (not shown). All seasonal cycles are smoothed with a 11-day running average to produce less noisy profiles, and only the extended summer part (15 April15 November) of the timeseries is used to exclude seasonal variability related to the winter Asian monsoon. When the zonal mean is removed from the seasonal cycles before the coefficient calculation, the zonally asymmetric signature of the monsoon is stronger (not shown), because the zonally symmetric meridional shifts with season are removed. EMED subsidence is almost perfectly correlated with strong ascent and precipitation over the northern parts of the Bay of
Bengal/Arabian Sea (poleward of $15^{\circ} \mathrm{N}$ ), and over a large continental area to the south of the Himalayas, stretching from eastern and northern Pakistan, northern India until Bangladesh. Evidently, there is a southeast-northwest gradient in the degree of synchronicity of the EMED subsidence seasonal evolution and that across the Asian summer monsoon system. The correlation patterns weaken over the western Pacific and reverses near the Equator (Fig. 7). In particular, the deepest convection and precipitation are observed over the eastern parts of the Bay of Bengal, though the highest correlation and synchronicity are found over northern continental India and the Arabian Sea. Note that the high correlation values over eastern Asia can be associated with the EASM and its simultaneous links with the ISM subsystem.

\subsection{Mechanism explaining the synchronicity pattern}

Deep convection over the tropical region can excite equatorially trapped and westward propagating Gill-type Rossby waves and eastward-moving Kelvin waves (Gill 1980; Rodwell and Hoskins 1996; Joseph and Srinivasan 1999). Idealized simulations performed by Rodwell and Hoskins (1996) with a primitive equation model revealed that when the diabatic heating source is located at a more northern latitude over the Bay of Bengal, the Rossby wave loses its equatorial symmetry and its Northern Hemisphere structure is significantly enhanced. The amplitude of the Rossby wave response is weak in easterly or in strong westerly basic zonal flow and increases in regions of near zero or weak westerly zonal flow (Lin et al. 2007; Lin 2009). During the summer an upper level easterly jet stretches from the western North Pacific to Africa south of $20^{\circ} \mathrm{N}$ (Fig. 3c). Thus, for tropical forcing associated with the WNPSM subsystem the Rossby wave response developing to its west will be suppressed due the prevalence of the easterly background flow. Within the ISM domain and for the early monsoon season, during late spring, again the Northern Hemisphere Rossby wave gyre will be weak and regionally confined. As the convection spreads towards the CIND region the heating source is located closer to the zero zonal flow area and thus, the Rossby wave gyre will be significantly enhanced. Especially when convection suddenly begins in late June over the northwesternmost location of the ISM domain (CIND), the Rossby wave response is expected to acquire its annual maximum over the Middle East, south of the upper level westerly subtropical jet. A warm structure and subsidence developing to the northwest of the diabatic heating are considered as a pure Rossby wave response (Rodwell and Hoskins 1996, 2001).

The above mechanism provides an explanation for the fact that subsidence over the EMED and Iran do not develop and intensify in situ but rather they migrate northwestward from their mid spring location in a 
strikingly similar fashion with the migration of the convective activity over the ISM domain. When convection starts over the southeastern Bay of Bengal in late April only a weak Rossby wave structure develops to the west that could be responsible for the initial strengthening of subsidence over the northwestern Arabian Sea. As the heating source migrates to higher latitudes, successive Rossby wave pulses are released that are gradually exposed to a more favorable basic flow environment for the Northern Hemisphere Rossby wave response to develop. This inference is consistent with previous studies of the interannual (Ding and Wang 2005; Lin 2009; Wang et al. 2001; Wang and Fan 1999) and intraseasonal (Ding and Wang 2007) convective variability across the summer Asian monsoon region, emphasizing the planetary-scale implications of the ISM convective variability. A key response is the development of an upper level ridge across west-central Asia above the surface thermal low resulting in a baroclinic structure that extends towards the EMME (Ding and Wang 2005, 2007). This feature is stronger in cases of an abnormally strong Indian summer monsoon and its presence can disturb the summer Asian jet wave guide and induce a downstream Rossby wave train resulting in a circumglobal teleconnection pattern across the Northern Hemisphere. On the other hand, the WNPSM variability induces a local signal and in regions mainly in the Southern Hemisphere (Lin 2009; Wang et al. 2001; Ding 2007). The fast Rossby wave response to the heating forcing, causing it to extend over the EMME and North Africa regions within approximately a week (Rodwell and Hoskins 1996), accounts for the synchronicity of the seasonal cycles of EMED subsidence and convective activity over the CIND, NARA and NBEN regions. Overall, the close correspondence of the intensity of the Etesians and the EMED subsidence highlights their common dynamical cause. Both are reconciled manifestations of the monsoon influence over the area.

\subsection{Thermodynamic state of the troposphere}

The development of the warm structure associated with the Rossby wave is studied here by considering the seasonal evolution of the tropospheric thermodynamic state over the EMME. Figures 8 and 9 depict snap shots of the seasonal pace of the monthly mean pressure-longitude profiles of Eq. 1 terms averaged over the latitude band $32-40^{\circ} \mathrm{N}$, for a selection of months. From February onward and mainly in March (not shown) the lower troposphere is heated from below through exchange of sensible heat with the surface. In April and May the heating continues especially over the extensive Tibetan plateau landmass (Fig. 8a, b). Most importantly, near the end of April upper level warming (LTT) develops at around $80-90^{\circ} \mathrm{E}$. In May and June it (a) LTT APR $32-40^{\circ} \mathrm{N}$

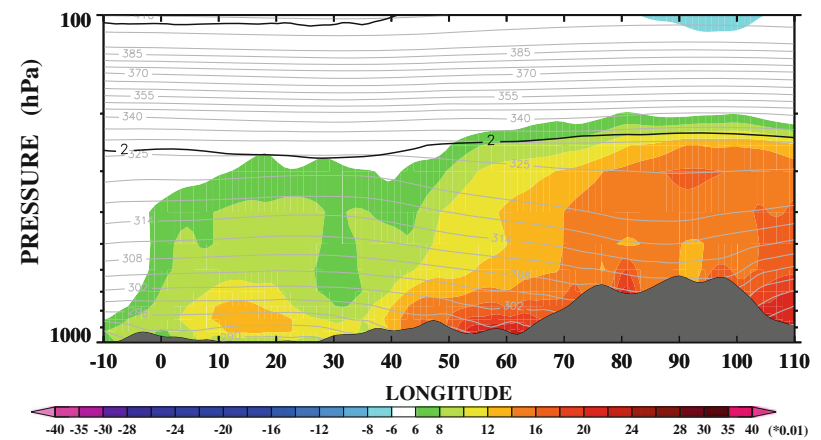

(b) LTT MAY $32-40^{\circ} \mathrm{N}$

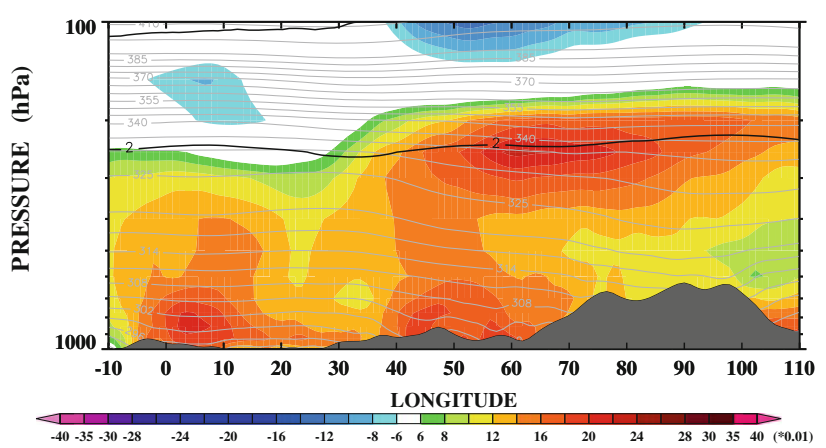

(c) LTT JUN $32-40^{\circ} \mathrm{N}$

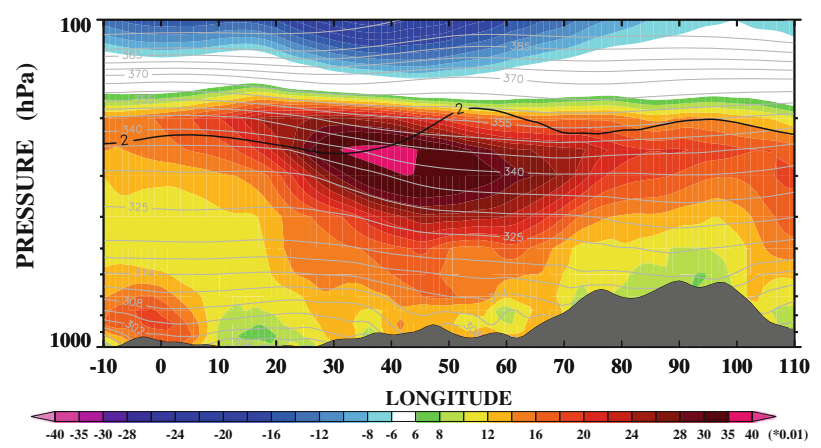

(d) VATT MAY $32-40^{\circ} \mathrm{N}$

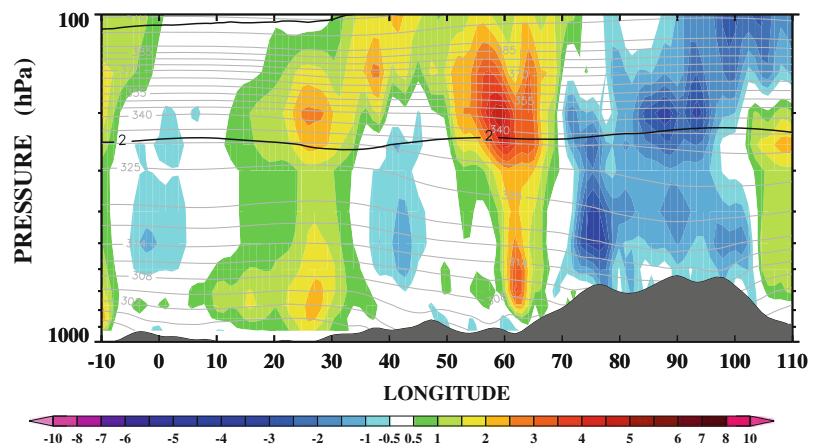

Fig. 8 Evolution of pressure-longitude profiles of monthly mean LTT (filled contours in K/day) and $\theta$ (contours in K) averaged over the sector $32-40^{\circ} \mathrm{N}$ for April (a), May (b) and June (c). Note that colour bar values are multiplied with $10^{-2} \mathrm{~K} /$ day. Similarly for (d) but for May VATT (K/day) climate. The thick line marks the dynamical tropopause. Orography is superimposed 
intensifies and moves westwards reaching the eastern Mediterranean in June. The warming, which weakens in July (not shown), reaches a maximum in the free atmosphere within the layer 400-200 hPa, away from diabatic heating sources near the surface or the monsoon convective activity.

In the idealized simulations performed by Rodwell and Hoskins (2001), the Rossby wave response to the simulated monsoon-like heating applied over the northern parts of the Bay of Bengal is characterized by descent to the west of $70^{\circ} \mathrm{E}$, having a maximum within the $400-200 \mathrm{hPa}$ layer (see their Fig. 5). Consistent with this, an envelope region of positive VATT values induced by widespread subsidence (sharply to the west of $70^{\circ} \mathrm{E}$ ) can be seen from early May initially over Iran (Fig. 8d), exactly when deep convection begins over the ISM area favoring the Rossby wave response. Its maximum lies within the 300-200 hPa layer and spreads towards the eastern Mediterranean as the monsoon season progresses approaching July (Fig. 9a) and is counterbalanced by cold advection (Fig. 9b).

The study of the horizontal structure of the thermodynamic state of the EMME at mid and upper levels is facilitated by the inspection of Figs. 10 and 11. Specifically, the July climatology of 500 and $200 \mathrm{hPa} \theta$ and horizontal wind can be seen in Figs. 10a and 11a, respectively. The corresponding July climatologies for the horizontal wind and TPTT, VATT and HATT are illustrated in Figs. 10b-d and $11 \mathrm{~b}-\mathrm{d}$, respectively. Evidently, the EMME represents a 'hot spot' and above $500 \mathrm{hPa}$ warming takes the form of a westward spreading high temperature ridge giving rise to a very steep northwest-southeast temperature gradient over the eastern Mediterranean, which is strongest in July, following the intense upper level heating in May and June.

Over the eastern Mediterranean and near the tropopause, the warming is the result of air subsiding in the vicinity of the steeply sloping isentropes following two paths. The first path involves airflow in the layer 100-200 hPa characterized by a strong southerly wind component (Fig. 12a) originating in South Asia and moving around the upper level anticyclone. It descends from pressure levels just above $100 \mathrm{hPa}$ to below $200 \mathrm{hPa}$ in the vicinity of the Mediterranean coast of northeastern Africa. Due to this distinct monsoon induced flow that appears in April simultaneously with the monsoon onset (not shown), the area of subsidence and associated adiabatic warming, which is partly offset by cold advection, extend up to nearly $100 \mathrm{hPa}$ over the eastern Mediterranean and the western part of the Middle East, higher than any other sector, including Iran (Fig. 9). The slightly stronger warming compared to cooling on the southern rim of the 'warm ridge' leads to its westward expansion along the northern coast of North Africa. Unlike the strong contribution of negative MATT over the eastern Mediterranean, due to the (a) VATT JUL $32-40^{\circ} \mathrm{N}$

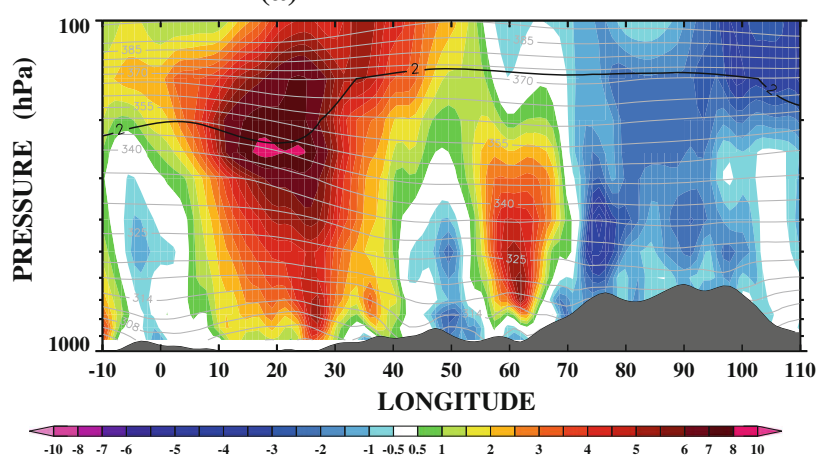

(b) HATT JUL $32-40^{\circ} \mathrm{N}$

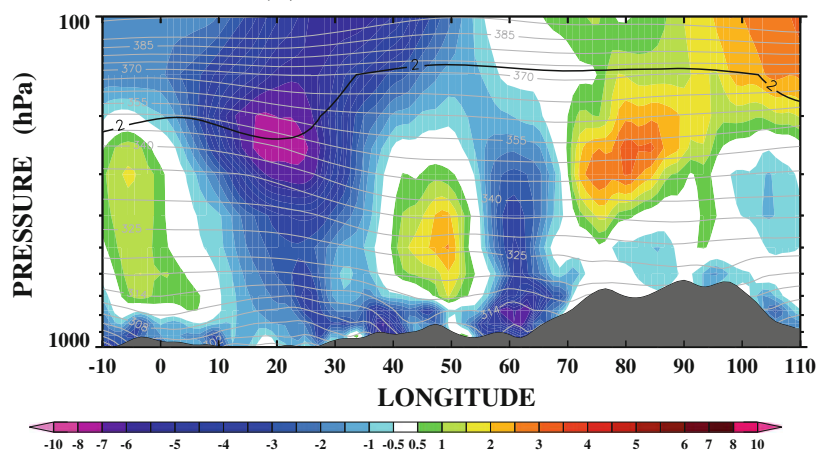

(c) MATT JUL $32-40^{\circ} \mathrm{N}$

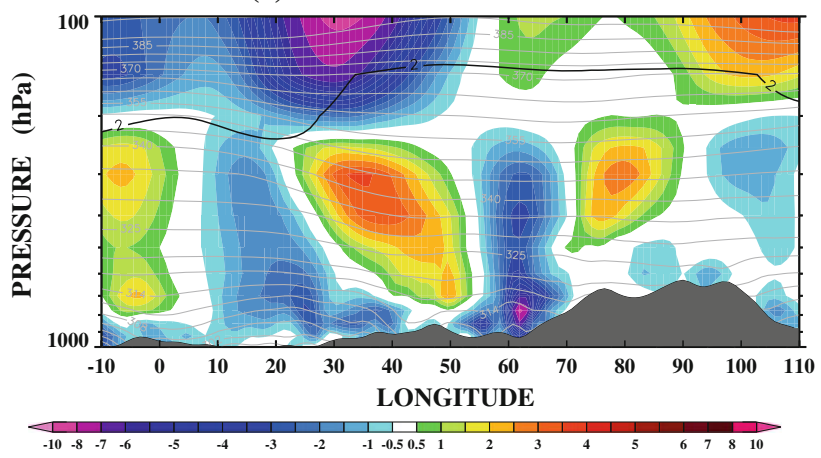

(d) ZATT JUL $32-40^{\circ} \mathrm{N}$

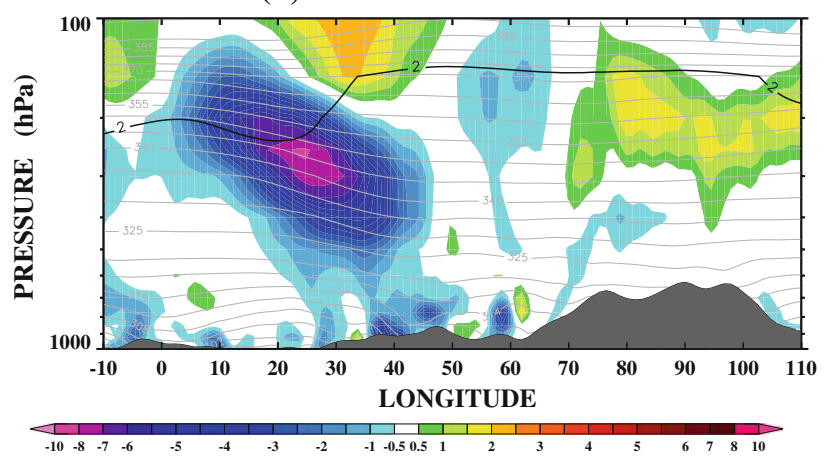

Fig. 9 Pressure-longitude profiles of mean July VATT (a), HATT (b), MATT (c) and ZATT (d) averaged over the sector $32-40^{\circ} \mathrm{N}$ (units of $\mathrm{K} /$ day). The dynamical tropopause (thick line) and the isentropes (thin lines) are also plotted. Orography is superimposed 
(a) WIND, $\theta$ JUL $500 \mathrm{hPa}$

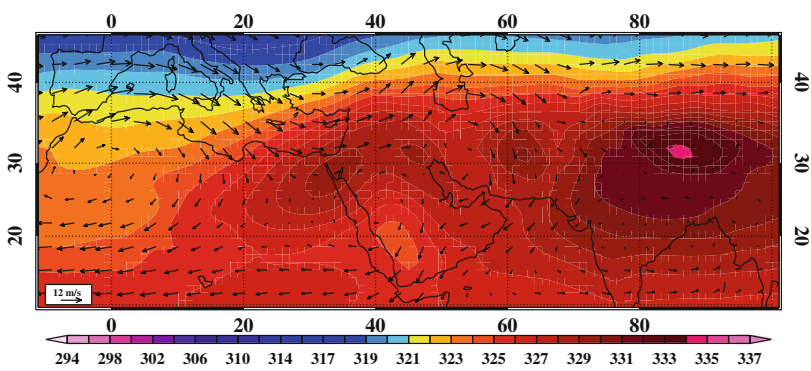

(b) WIND,TPTT, $\theta$ JUL $500 \mathrm{hPa}$

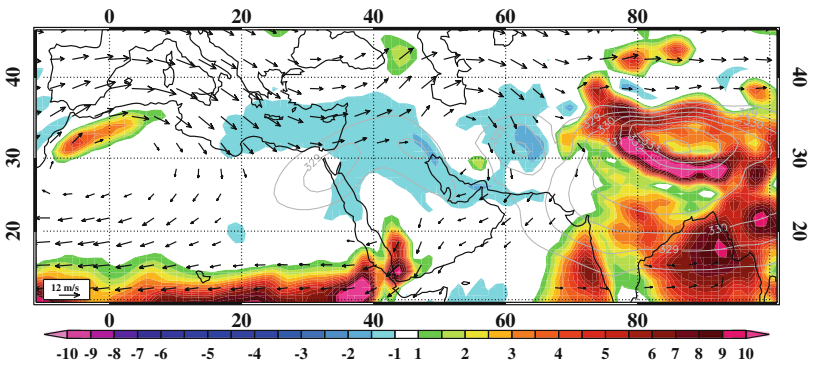

(c) WIND,VATT, $\theta$ JUL $500 \mathrm{hPa}$

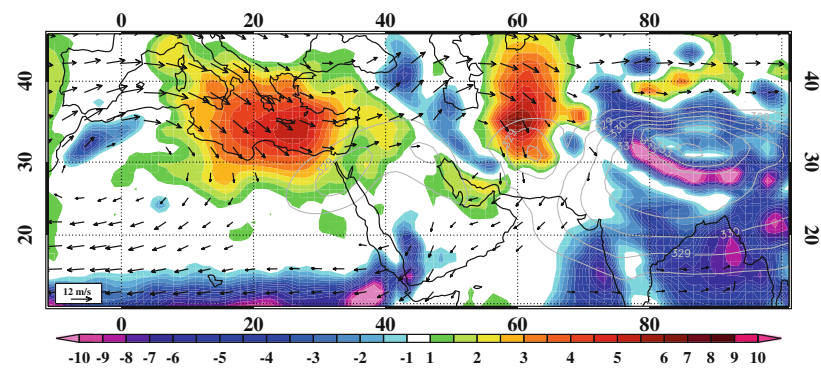

(d) WIND,HATT, $\theta$ JUL $500 \mathrm{hPa}$

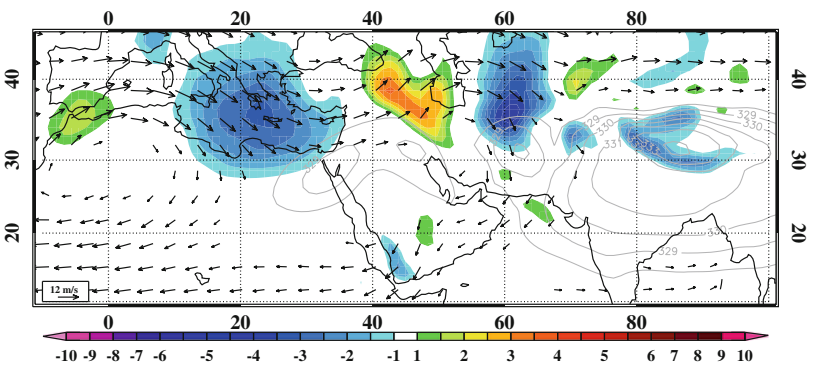

Fig. 10 Mean July $500 \mathrm{hPa}$ wind and $\theta$ (a), TPTT (b), VATT (c) and HATT (d). Units are K/day. For b-d the $\theta$ isolines are depicted only for values higher than $328 \mathrm{~K}$, while wind vectors are suppressed for speeds below $4 \mathrm{~m} / \mathrm{s}$. For illustration purposes vectors are plotted every third column or row of grid points

temperature gradient reversal above $200 \mathrm{hPa}$ and the southerly flow, such a contribution is not detected in the second most significant area of subsidence over Iran (Fig. 9c).

The second process involves the mid and upper level midlatitude westerly flow component, which is stronger in the northern parts of the EMME. Over the eastern Mediterranean, air is flowing downward along the isentropes, characterized by a steep east-west slope induced by the South Asian monsoon (a) WIND, $\theta$ JUL $200 \mathrm{hPa}$

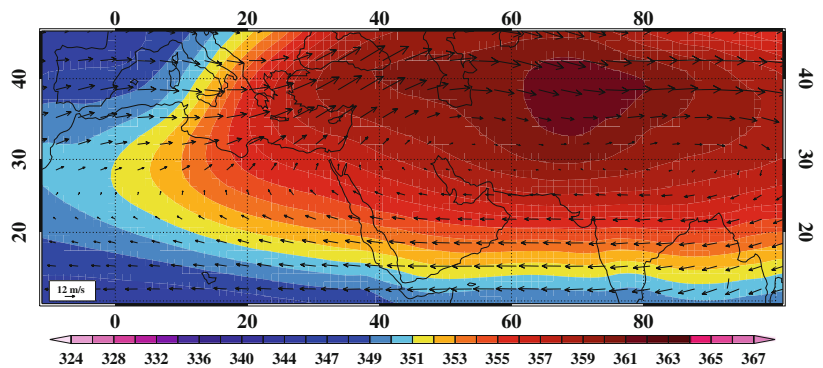

(b) WIND,TPTT, $\theta$ JUL $200 \mathrm{hPa}$

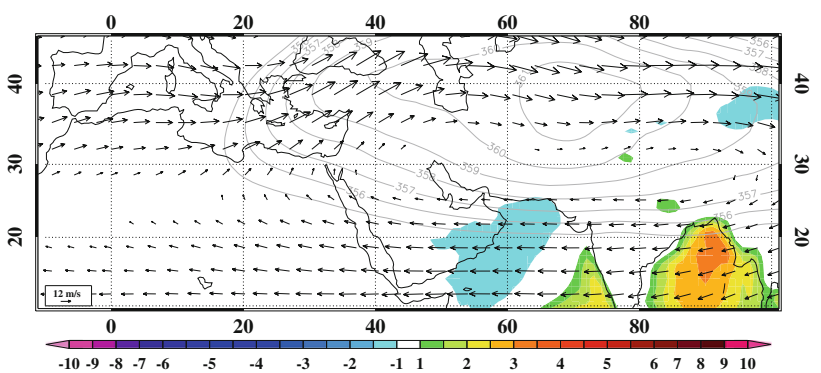

(c) WIND, VATT, $\theta$ JUL $200 \mathrm{hPa}$

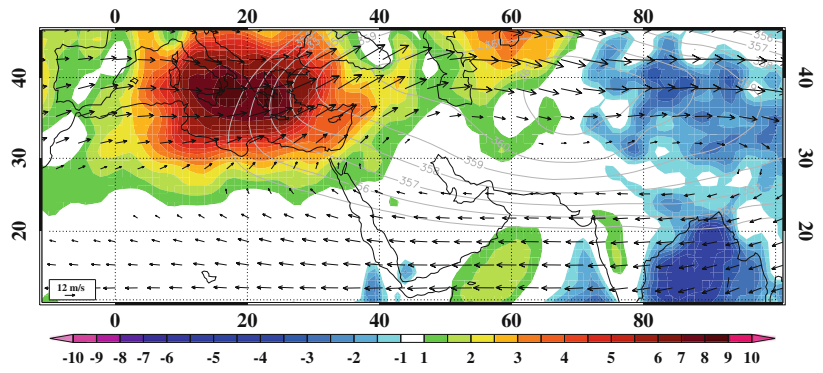

(d) WIND,HATT, $\theta$ JUL $200 \mathrm{hPa}$

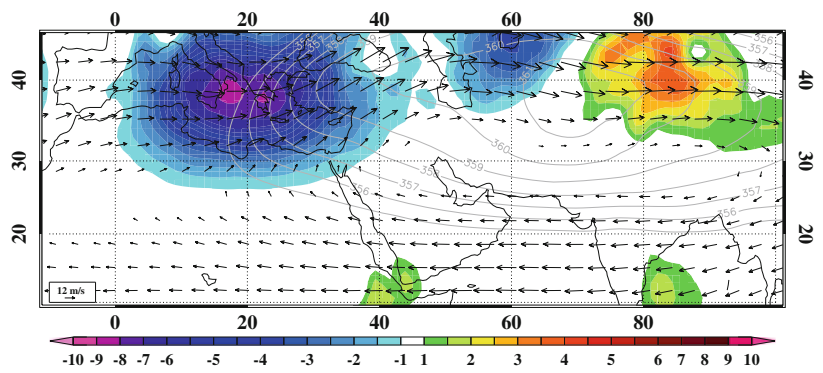

Fig. 11 Mean July $200 \mathrm{hPa}$ wind and $\theta$ (a), TPTT (b), VATT (c) and HATT (d). Units are K/day. For b-d the $\theta$ isolines are depicted only for values higher than $355 \mathrm{~K}$, while wind vectors are suppressed for speeds below $5 \mathrm{~m} / \mathrm{s}$. For illustration purposes vectors are plotted every third column or row of grid points

(Fig. 12b). This results in a 400-200 hPa level ZATT minimum and this flow primarily contributes to the distinct HATT minimum and equivalent VATT maximum (Fig. 9). Further to the east, over Turkey, the Caucasus and the Black Sea, both currents merge into a strong upper level southwesterly subtropical jet over central Asia (Fig. 11). This region of strong wind shear is also a hot spot of cross-tropopause mixing (Traub and Lelieveld 2003). Consistent with the weaker mid and upper level zonal 
(a) JUL V $24-28^{\circ} \mathrm{E}$

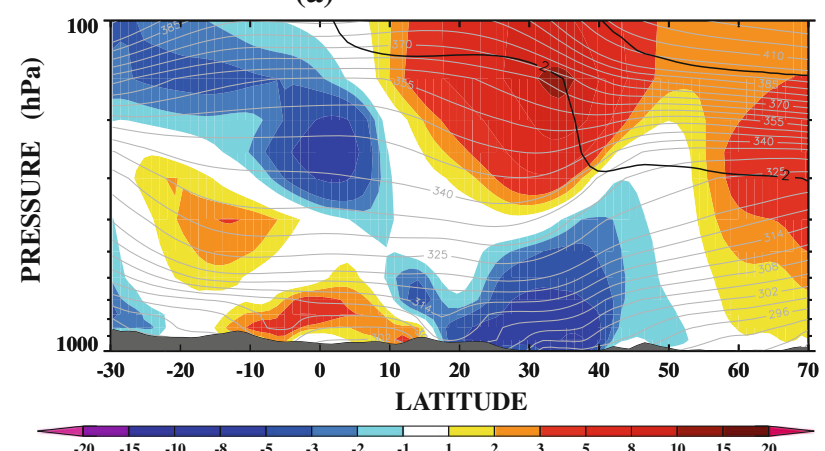

(b) JUL U $32-40^{\circ} \mathrm{N}$

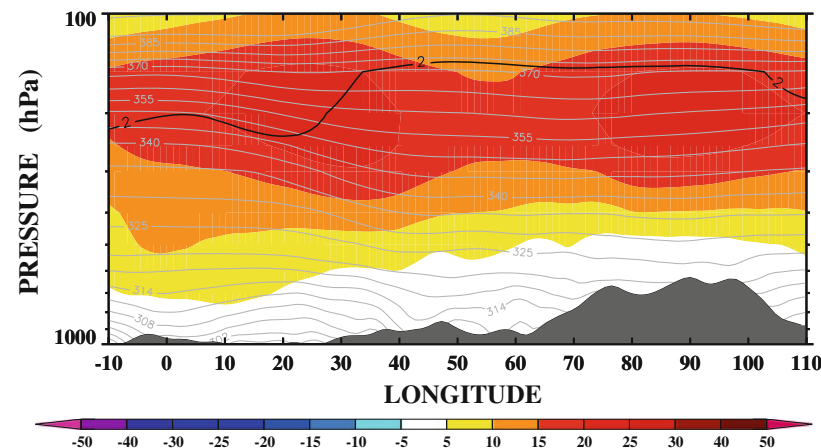

Fig. 12 (a) Pressure-latitude profile of mean July meridional wind averaged over the sector $24-28^{\circ} \mathrm{E}$. (b) Pressure-longitude profile of mean July zonal averaged over the sector $32-40^{\circ} \mathrm{N}$. The dynamical tropopause (thick line) and isentropes (thin lines) are superimposed. Note the different shading interval used for the two wind components. Orography is superimposed

temperature gradient over Iran and weaker zonal flow, subsidence over this area (and the associated horizontal advection cooling and vertical advection warming) is mainly the result of the southward flow in the enhanced meridional temperature gradient environment. Thus, the quantification and analysis of HATT into its zonal and meridional components indicates that over both the eastern Mediterranean and Iran below $300-200 \mathrm{hPa}$ the subsiding air primarily originates from midlatitudes. However, further aloft the subsidence over the eastern Mediterranean and related changes in upper tropospheric thermodynamic state are related to air originating in South Asia. Most importantly, there is no evidence for a uniform subsidence branch over the EMME that is driven by monsoon ascent over South Asia, but the midlatitude contribution is significant.

\section{The effect of topography}

\subsection{Subtropical anticyclones and low level circulation} features

Thus far we focused on the mid and upper tropospheric EMME circulation, which is dominated by the free (a) WIND, $\theta$ JUL $850 \mathrm{hPa}$

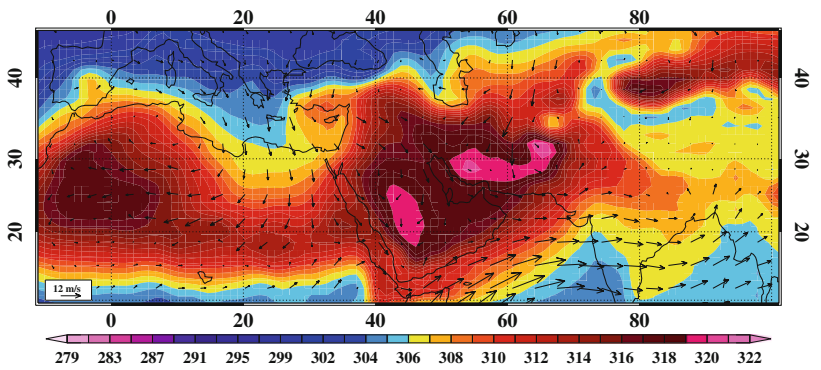

(b) WIND,TPTT, $\theta$ JUL $850 \mathrm{hPa}$

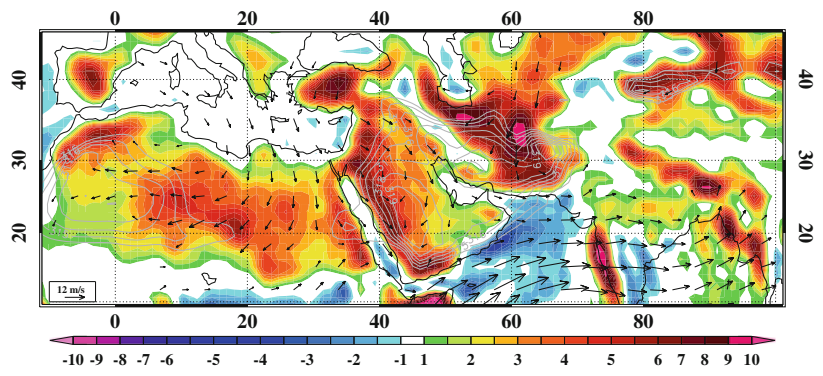

(c) WIND,VATT, $\theta$ JUL $850 \mathrm{hPa}$

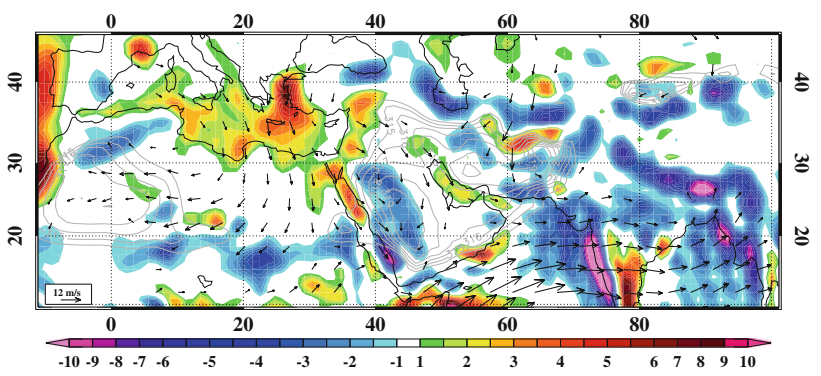

(d) WIND,HATT, $\theta$ JUL $850 \mathrm{hPa}$

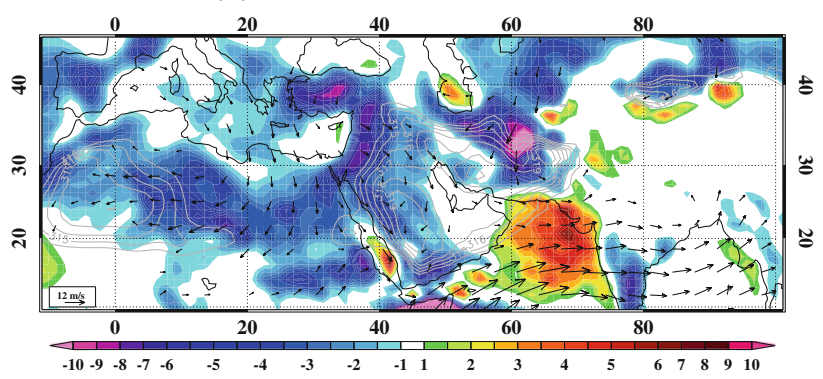

Fig. 13 Mean July $850 \mathrm{hPa}$ wind and $\theta$ (a), TPTT (b), VATT (c) and HATT (d). Units are K/day. For b-d the $\theta$ isolines are depicted only for values higher than $314 \mathrm{~K}$, while wind vectors are suppressed for speeds below $3 \mathrm{~m} / \mathrm{s}$. For illustration purposes vectors are plotted every third column or row of grid points

tropospheric heating associated with the monsoon induced Rossby wave. Here with the addition of Fig. 13, which shows the horizontal structure of the thermodynamic state of the EMME at $850 \mathrm{hPa}$, we discuss the influence of topography. Elevated surface heating over the high terrain across the region introduces significant low and mid level undulations in the isentropes superimposed onto the large 
scale background pattern. These undulations are evident in the mean July pressure-longitude profiles of $\theta$ and TPTT shown in Fig. 14a, b, which cut through the principal high terrain areas and high TPTT values (Fig. 13b). Due to the highly elevated orography, the induced surface heating is evident in the layer 600-300 hPa over the Tibetan plateau, at $800-600 \mathrm{hPa}$ over the Zagros mountains (Fig. 14a) and at $900-700 \mathrm{hPa}$ over central western Saudi Arabia (Fig. 14b). The accumulated heating during the previous months results in a depression of the isentropes in the sectors $75-95^{\circ} \mathrm{E}, 50-60^{\circ} \mathrm{E}$ and $40-45^{\circ} \mathrm{E}$, respectively. Overall, the 850 hot spots coincide with the large positive TPTT values over high terrain.

The location of the subtropical anticyclones in the mid and upper troposphere over the most prominent mountain ranges in Africa and Asia highlights the role of elevated surface heating sources in their formation. Indeed, during the transition from spring to summer, the mid level anticyclonic centers over South Asia and North Africa move towards the north until they reside over northwest Africa, central western Saudi Arabia and the Zagros mountains (see also Zarrin et al. 2010). To some extent, aspects of the influence of the elevated terrain on the circulation can be explained with the aid of the pressure-longitude profiles of divergence averaged in the latitude zones $28-32^{\circ} \mathrm{N}$ and $22-28^{\circ} \mathrm{N}$ (Fig. $14 \mathrm{c}$, d). Intense surface heating of the air adjacent to the mountain slopes results in the redistribution of air masses with low level convergence and divergence further aloft, giving rise to mid or upper level anticyclonic circulation. The vast area of upper level divergence over the Tibetan plateau to the east of $70^{\circ} \mathrm{E}$ is located much higher than the outflow levels over western Saudi Arabia (Fig. 14d, $40-45^{\circ} \mathrm{E}$ at $600 \mathrm{hPa}$ ), the Zagros mountains (Fig. $14 \mathrm{c}, 45-55^{\circ} \mathrm{E}$ at $500 \mathrm{hPa}$ ) and northwest Africa (Fig. $14 \mathrm{c}, 0-10^{\circ} \mathrm{E}$ at $600-700 \mathrm{hPa}$ ). As a result at 200 and $100 \mathrm{hPa}$ only the vast Tibetan anticyclone is visible (Zarrin et al. 2010). Beyond the thermodynamically induced circulation in the vicinity of mountains due to elevated surface heating, mountains can also have strong dynamical influence on the circulation through blocking of the westerly flow and leading to more complex circulation patterns. Such a dynamical influence is expected to be more important over northwest Africa, where the westerly flow is stronger, rather than over the Middle East. This could explain the larger vertical extent of the divergence pattern observed over the former region and also the existence of a diabatic forcing vertical tripole over the northwestern tip of Africa, with cooling at 600-700 hPa (Fig. 14a). However, the depression of the isentropes is still present in the sector $5^{\circ} \mathrm{W}-5^{\circ} \mathrm{E}$. Also, the influence of the colder Mediterranean waters is evident ( $\theta$ ridge) in the sector $10-35^{\circ} \mathrm{E}$.

Thus, the intense surface heating over the vast Middle East arid regions 'erodes' the envelope subsidence over the
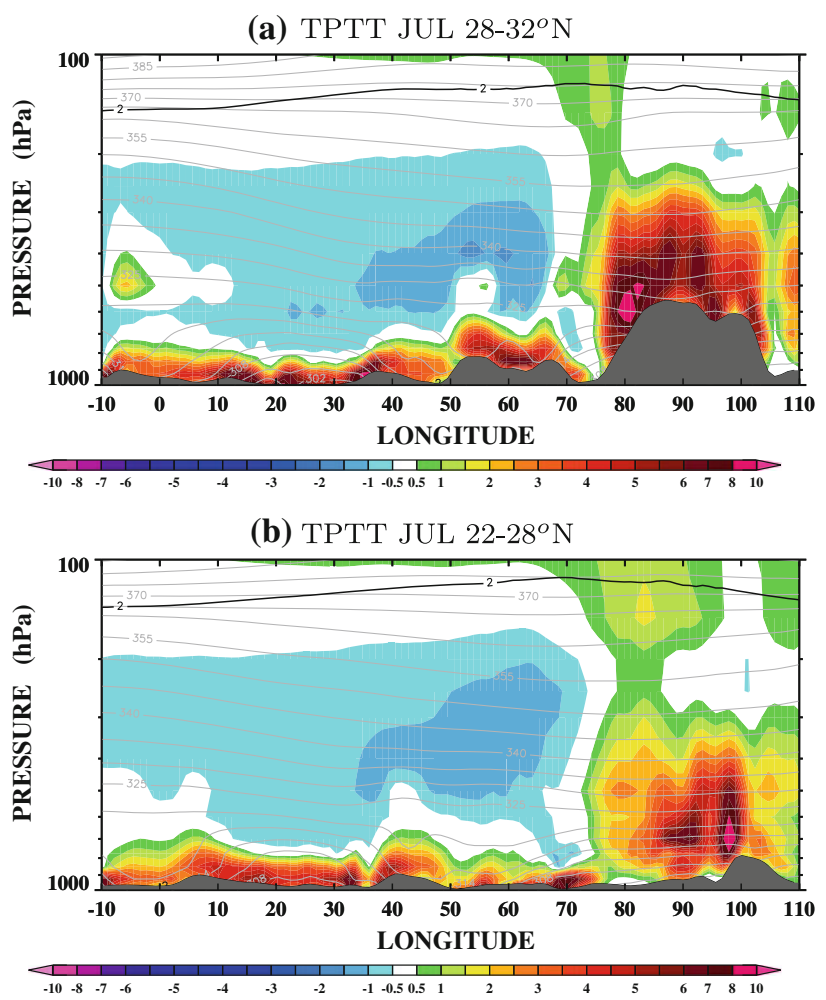

(c) DIV JUL $28-32^{\circ} \mathrm{N}$

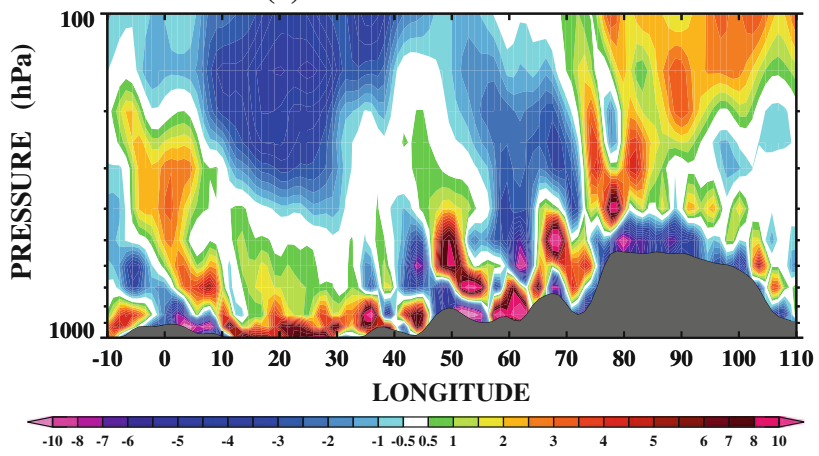

(d) DIV JUL $22-28^{\circ} \mathrm{N}$

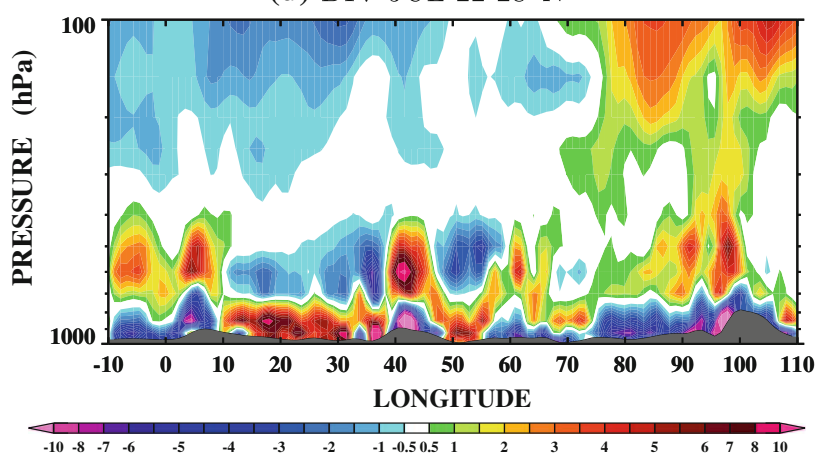

Fig. 14 Pressure-longitude profiles of TPTT (K/day) averaged over the latitude bands $28-32^{\circ} \mathrm{N}$ (a) and $22-28^{\circ} \mathrm{N}$ (b). Similarly for divergence averaged over the latitude bands $28-32^{\circ} \mathrm{N}$ (c) and $22-28^{\circ} \mathrm{N}$ (d). Red (blue) colours denote divergence (convergence). Note that color bar values for divergence should be multiplied by $10^{-6} \mathrm{~s}^{-1}$ 
Fig. 15 Mean July $500 \mathrm{hPa}$ wind, $\theta$ and HATT + VATT (shaded). The $\theta$ isolines are depicted only for values higher than $328 \mathrm{~K}$, while wind vectors are suppressed for speeds below $4 \mathrm{~m} / \mathrm{s}$. For illustration purposes vectors are plotted every third column or row of grid points
WIND,HATT+VATT, $\theta$ JUL $500 \mathrm{hPa}$

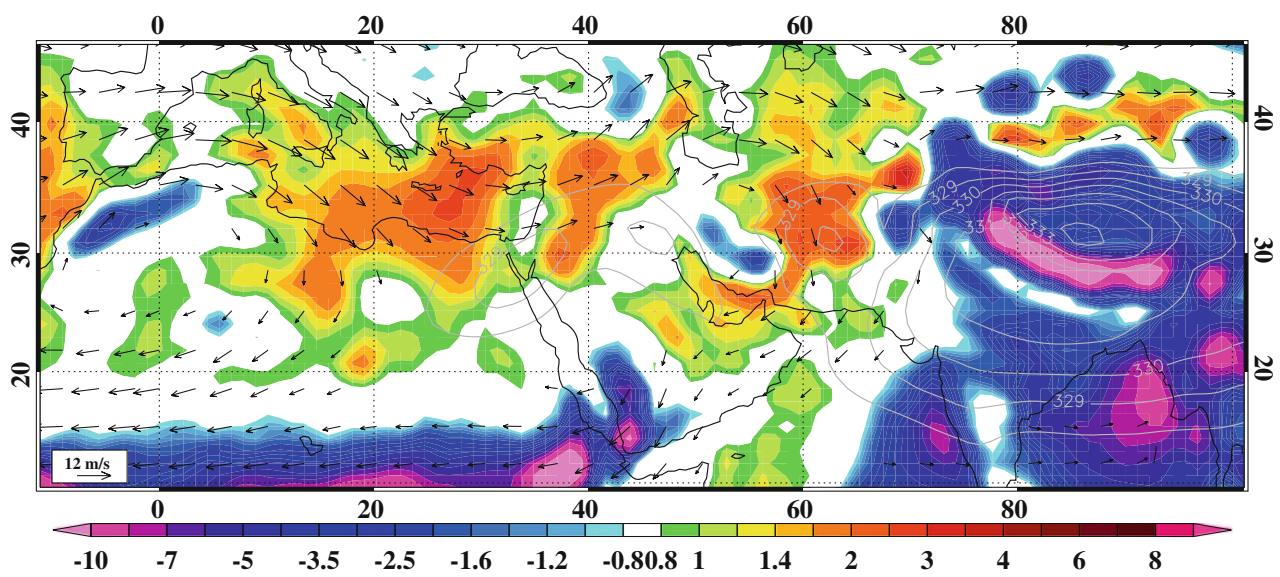

area from below resulting in 'pockets' of shallow dry convection, such as over the high terrain in central western Saudi Arabia, where low level convergence is observed at $40-45^{\circ} \mathrm{E}$, with maximum ascent in the $800-700 \mathrm{hPa}$ level (Fig. 4d). The mainly dry character of convection is confirmed by the lack of significant mid level positive TPTT induced by latent heat. This deviates from the moist convection observed at the southwestern tip of the peninsula, where the cold vertical advection and warming due to latent heat release dominate the thermodynamic energy budget (Fig. 10). The northerly flow and low level subsidence are very strong around the Arabian peninsula 'dry convection island' and especially over the neighboring water bodies and low surface areas of the Red Sea, the Persian Gulf and Iraq. Funneling effects act to accelerate the flow in these landlocked air masses. Closer examination reveals that these low levels jets always develop at the western side of high terrain areas that induce a depression of the isentropes. Along the Red Sea at $35-40^{\circ} \mathrm{E}$ the isentropes exhibit a steep slope up to $700 \mathrm{hPa}$ (Fig. 14b) and subsidence is favored as air moves southeastwards. This area of subsidence is sandwiched, as weaker ascent is also observed over eastern Egypt (Fig. 4d). The surface heating induced by the elongated mountain range stretching from the Zagros mountains to southeastern Turkey, is visible at $700 \mathrm{hPa}$ (Fig. 14a). The low level jet and subsidence again develop along the western flank of the axis of the isentropic trough depicted around $50^{\circ} \mathrm{E}$ in Fig. 14a. Thus, both the low level jet over the Red Sea and the Iraq-Gulf regions, which originate in the mid troposphere over the eastern Mediterranean, are manifested at the surface and intensify due to the interaction with topography. Similarly, the depression of the isentropes at $65-70^{\circ} \mathrm{E}$ over eastern Afghanistan (Fig. 14a) favors subsidence to its northwest. Even the intense subsidence and strong northerly flow observed over the eastern Aegean are located at the western flanks of the surface heating over the Anatolian plateau, which introduces an enhanced temperature gradient over the Aegean in the northwest-southeast direction.

\subsection{Mid level 'hot spots'}

The major areas of low and mid tropospheric mean July subsidence over the eastern Mediterranean and Iran are located at the eastern flanks of the anticyclonic centers over northwest Africa and the Zagros mountains, respectively. The pronounced southward advection observed in these areas enhances subsidence along the isentropes. Thus, topography acts to focus and localize the envelope subsidence area induced by monsoon convection. Rodwell and Hoskins (1996) pointed out the importance of orography by showing that removal of the aforementioned mountain regions in their simulations leads to the reduction of subsidence to their east. The $500 \mathrm{hPa}$ temperature hot spots over northern Saudi Arabia, northeast Egypt and Afghanistan are exactly located to the south or downstream the areas of strong northerly flow and subsidence over the eastern Mediterranean and Iran, also marking the excess of VATT relative to HATT, depicted in Fig. 15. Thus, accumulated heating during the end of spring and the beginning of summer leads to the gradual formation and northward expansion of these hot spots. This highlights the significant indirect influence of topography, mainly on the mid tropospheric thermodynamic state, added to the direct and larger scale influence induced by the Tibetan plateau and monsoon activity to the mid and upper troposphere circulation discussed in Sect. 4.

Radiative cooling occurs in the vicinity of these 'hot spots', under clear skies formed as air moves away from saturation due to the excessive adiabatic warming. It is more intense in the mid troposphere, where the air is denser and warmer than aloft (Fig. 14a, b), and until July it cannot balance the increasing excess of VATT against HATT that leads to warming. From late July onward, when the 
(a) VATT AEGEAN

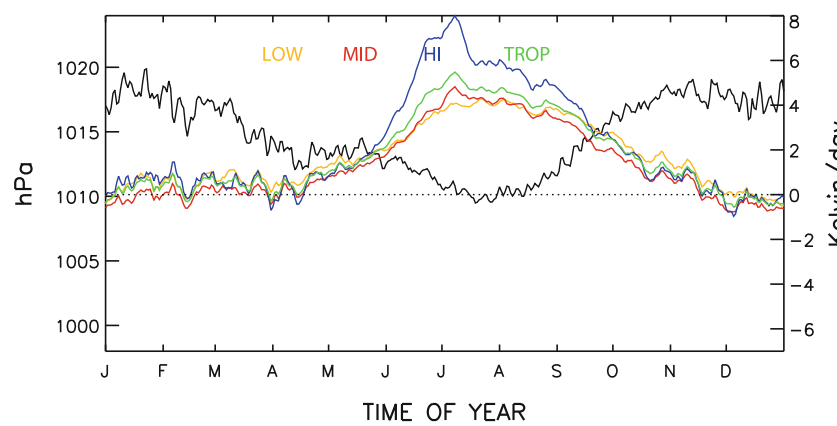

(c) VATT IRAN

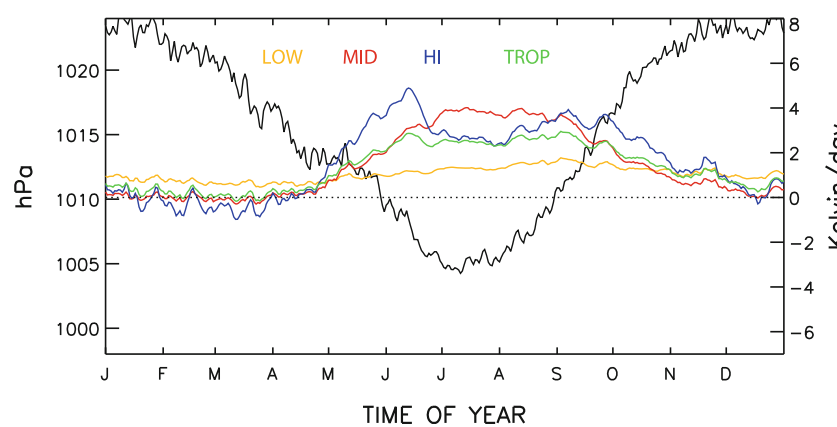

(e) LTT IRAQ

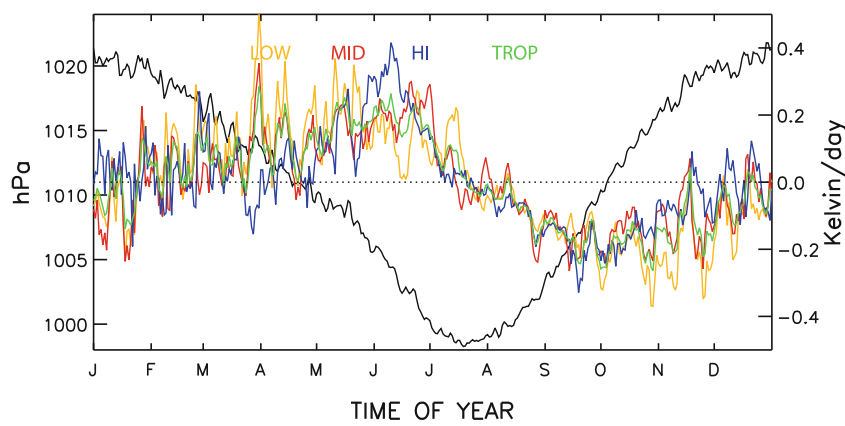

(g) VATT+HATT ARABIA

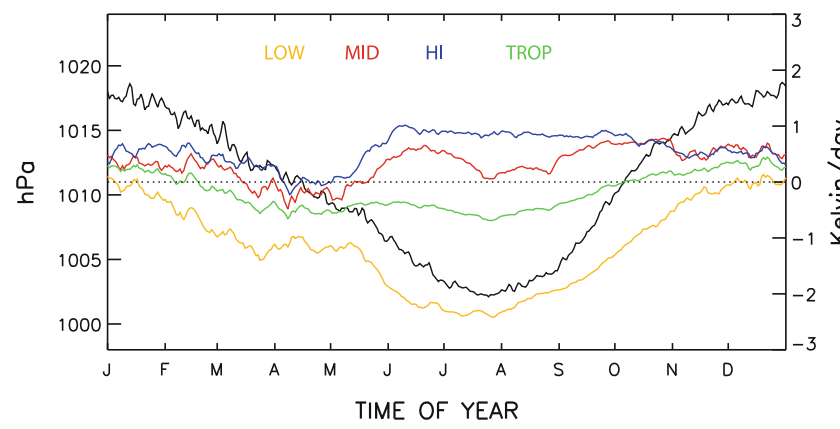

Fig. 16 Seasonal evolution of MSLP (black line) and thermodynamic energy equation terms averaged in the lower troposphere (orange: 925-700 hPa), mid troposphere (red: $600-400 \mathrm{hPa}$ ), upper troposphere (blue: $300-200 \mathrm{hPa}$ ) and the whole tropospheric column (green: 925-200 hPa). Variables are averaged over the Aegean Sea (b) HATT AEGEAN

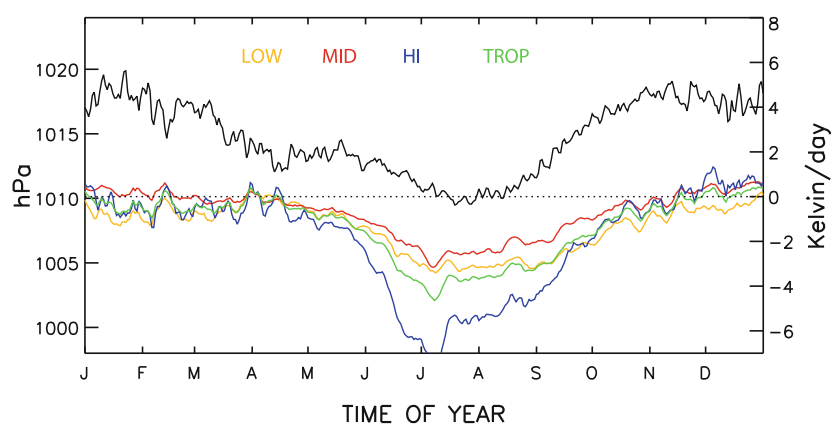

(d) TPTT IRAQ

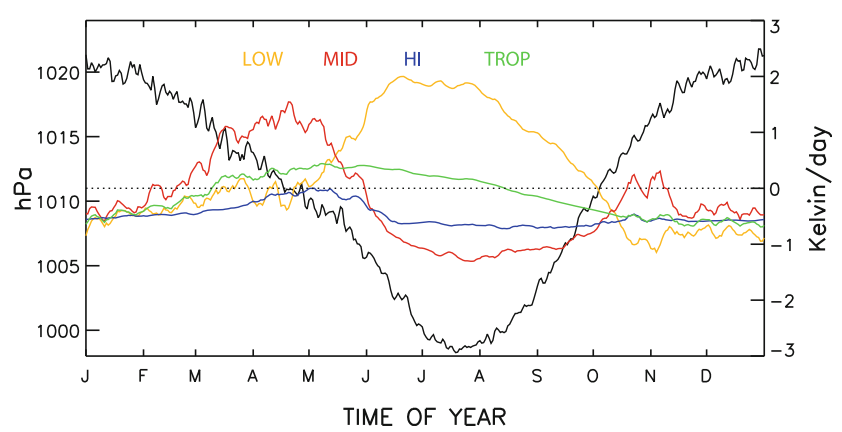

(f) $\mathrm{VATT}+\mathrm{HATT}$ IRAQ

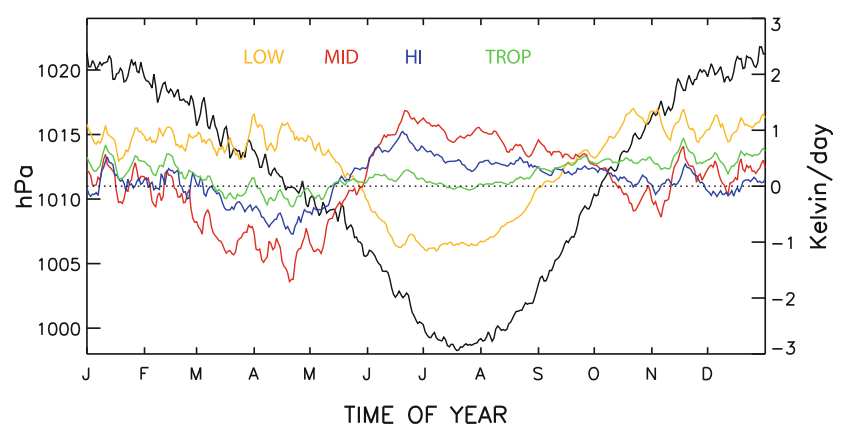

(h) VATT+HATT CYPRUS

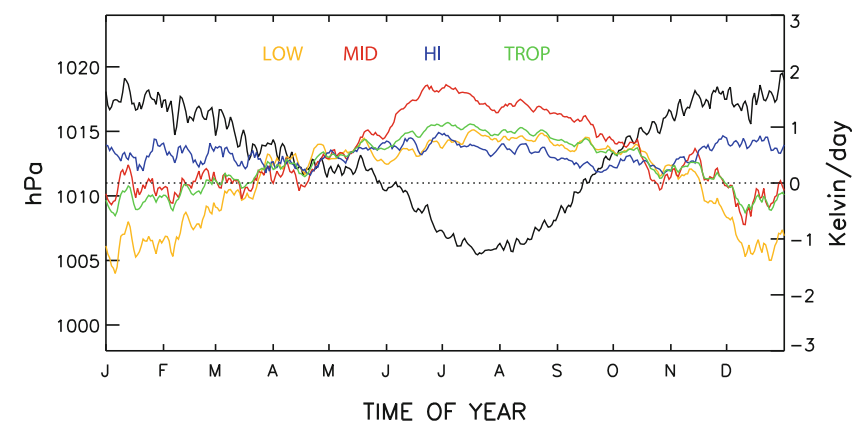

$\left(24.5-28.5^{\circ} \mathrm{E}: 34-41^{\circ} \mathrm{N}\right), \quad \operatorname{Iran} \quad\left(57-65^{\circ} \mathrm{E}: 31-45^{\circ} \mathrm{N}\right)$, northern Iraq $\left(42-47^{\circ} \mathrm{E}: 32-35^{\circ} \mathrm{N}\right)$, central western Saudi Arabia $\left(38.5-46^{\circ} \mathrm{E}\right.$ : $\left.19-30^{\circ} \mathrm{N}\right)$ and in the vicinity of Cyprus $\left(29-36^{\circ} \mathrm{E}: 34-37^{\circ} \mathrm{N}\right)$. All timeseries are smoothed with a 11-day running average 
monsoon induced circulation weakens, the opposing effect of the steady radiative cooling contributes to the waning and from August the reversal of the mid and upper troposphere temperature anomalies. Unlike the surrounding regions, to the southwest of the Caspian Sea, the $500 \mathrm{hPa}$ flow is southerly with air flowing up along the isentropes (negative VATT) and advecting warm air (positive HATT), as depicted in Fig. 10c, d.

\subsection{Detailed seasonal cycle of the thermodynamic state over the EMME. The Persian trough MSLP minimum}

Thus far we mainly presented results corresponding to aspects of the thermodynamic state over the EMME during the peak of monsoon activity in July. Further insight into the seasonal progression of the thermodynamic equation terms averaged over selected areas of the EMME is gained by investigating the profiles shown in Fig. 16. The seasonal cycles are averaged within the tropospheric layers listed in the caption and are the result of two main processes. The first involves the mid-upper troposphere warm structure that gradually spreads northwestwards until early July and then retreats back southeastwards in close relation to the monsoon intensity variability illustrated by Fig. 6. As a result, the tight temperature gradient that favors upper level VATT and HATT extremes reaches its westernmost position over the Aegean in early July, almost a month later compared to Iran (blue curve in Fig. 16a-c). In the areas between the eastern Mediterranean and the Indian Ocean, e.g. over Iran, the temperature gradient passes twice during the monsoon intensification-advance and decay-retreat phases, leading to advective term extremes in early June and weaker ones in September. The second factor involves the seasonal migration and variability of the major subtropical anticyclonic centers over Africa and the EMME. Due to the intense summer elevated surface heating (see orange line in Fig. 16d), these centers amplify and reside over high terrain regions resulting in localized enhancement mainly of the mid level subsidence and the advection terms extremes.

Over all regions, the MSLP seasonal cycle is synchronous to the mean tropospheric temperature. Indeed, MSLP drops when the LTT averaged up to $200 \mathrm{hPa}$ increases (Fig. 16e; green line), the latter representing essentially the average temperature tendency in the overlying atmospheric volume, and continues to drop until the troposphere starts to cool in late July. The sharpest MSLP decrease occurs in June during the maximum upper level warming, which highlights the dominant role of the upper troposphere adiabatic warming (Fig. 16e; blue line). Note that for brevity, the seasonal profile of LTT is shown only for Iraq where warming is more intense, less variable and more pronounced across the whole EMME, contributing to the observed MSLP minimum, i.e. the Persian trough over the area. A contribution to the excess warming in the vicinity of the Persian trough also comes from the stronger mid and low level warming observed in the area compared to neighboring regions. For example, mid and low level HATT + VATT over Iraq during the summer are higher compared to those over central western Saudi Arabia (orange and red lines lines, Fig. 16f, g). This is mainly caused by the low and mid level positive VATT over Iraq, in accordance with the low level subsidence discussed above, as opposed to the negative VATT over Saudi Arabia (Fig. 13). Given the similar TPTT profiles over the two regions, the low level contribution can explain the excess total column warming over Iraq.

Similarly increased low and mid level HATT + VATT values are observed throughout the axis of the Persian trough, until Cyprus region (Fig. 16h) and even the Aegean Sea, which contribute significantly to the increased mean tropospheric HATT + VATT values, in the absence of significant surface warming over the Mediterranean Sea. A key factor explaining this warming across the Persian trough is the elongated mountain range to the north of the trough, because it obstructs the cooling induced by the general northerly flow that opposes adiabatic warming (VATT) and surface heating (TPTT). This ventilation is more effective over the more exposed areas of Turkey, along the Mediterranean coast of the Middle East, western Saudi Arabia and at the eastern flank of the Persian trough axis. In the vicinity of Cyprus, leeward of the Anatolian mountain range, actually weak surface warm advection (HATT) is observed at $850 \mathrm{hPa}$. Adiabatic warming caused by foehn-type wind on the lee side of the mountain range contributes to the warming of the low troposphere (also locally aggravating heat wave conditions) and the expansion of the trough towards the Mediterranean. Further study or preferably idealized simulations would help substantiate the aforementioned causalities derived by observations.

\section{Summary and conclusions}

The South Asian monsoon appears to be a fundamental driver of the summer EMME circulation, and its seasonal evolution is controlled by reversals in the differential landocean heating, which in turn are driven by the seasonal solar declination cycle. The recurrent circulation type over the region every summer is attributed to the climatological stability of the monsoon signal, a prominent feature of the global circulation. Deep convection in the tropics can excite equatorially trapped Rossby waves with a weak amplitude under easterly or strong westerly basic zonal flow, increasing under near-zero or weak westerly zonal 
flow. A warm core and subsidence are key ingredients of these westward propagating structures. By quantifying the thermodynamic energy equation terms, we studied the seasonal changes of the thermodynamic state of the troposphere over the whole region and investigated the dynamics leading to the observed EMME circulation.

In agreement with previous idealized model simulations, strong mid and upper level warming was identified to spread westward causing significant depression of the isentropes, which occurs in the free troposphere away from diabatic heating sources, and is linked to the Rossby wave activity. As this structure expands northwestwards sharp slopes in the isentropes are created over the EMME, which further facilitates subsidence since the western and northern periphery of the warm structure is exposed to the midlatitude westerlies. The Rossby wave response is characterized by a baroclinic signature with an upper level ridge and a low level trough expanding westward, while the steep MSLP gradient gives rise to the Etesians. In this sense, both subsidence and the northerly flow over the EMME are reconciled manifestations of the Rossby wave structure triggered by the monsoon convection.

In late spring, the area of monsoon convection is located under the strong easterly jet leading to a weak Rossby wave response and a weak subsidence signal over the EMME. As convection migrates towards its northernmost location, over northern continental India in early July, it is positioned below a weak easterly or even westerly flow, and the Rossby wave structure amplifies, impacting the EMME circulation, as implied by the strikingly synchronous seasonal cycle of the EMED subsidence and northerly flow with that of the monsoon activity. Given that monsoon convective activity is associated with breaks and amplification phases, it can be argued that successive Rossby wave 'pulses' are released, each one inducing a cumulative effect over the EMME, until the peak of the monsoon activity is reached in July. This continuous process can explain why the regions of summer subsidence do not develop in situ over the EMME but advance with the seasons following distinct paths and always to the northwest of the convection area. This zonally asymmetric circulation induced by the monsoon explains the anomalous latitude and strong free tropospheric subsidence observed over the EMME, much beyond the zonally typical values associated with the descending branch of the Hadley Cell. The weak synchronicity of the seasonal cycle of the EMED circulation with that of convection over the western parts of the North Pacific suggests the weak influence of convection over the latter region on the EMED circulation.

The influence of topography is important because it modifies the lower part of this large scale background state that expands westwards. On the one hand, elevated surface heating over the high terrain contributes to the formation of mid level anticyclonic centers during summer, mainly over northwest Africa, central western Saudi Arabia and the Zagros mountains. Enhanced northerly flow and consequently stronger subsidence are induced to their east over the eastern Mediterranean and Iran. On the other hand, the complex topography leads to funneling effects and amplification of subsidence and the northerly flow over the Aegean, the Red Sea, the Iraq-Gulf region and to the east of the Caspian Sea. Also, the massive mountain range extending from Turkey to Iran blocks the northerly flow contributing to further warming on its lee side. Thus, it plays an important role in the formation of the Persian trough to the south of the mountain range axis.

In the upper troposphere and lower stratosphere, the overwhelming magnitude of the observed EMME subsidence is related to air arriving from South Asia. Analysis of the zonal and meridional components of the horizontal advection term confirms that subsidence at mid and lower levels is primarily driven by the midlatitude westerly flow. The heterogeneity of the dynamics involved implies that the observed subsidence is not the result of a uniform branch, as a part of a broader 'Walker type' overturning circulation. Such a closed circulation would probably require a few weeks to fully establish. However, the striking almost concurrent development of the EMED circulation and the convective monsoon activity is supported by the concept of Rossby wave propagation, hence there is no need to assume such a closed circulation. Instead, the induced structure can develop in the area within a week, with the local circulations being able to quickly adjust to the large scale forcing. Details of the modification of the large scale state induced by the monsoon due to signals originating in the midlatitudes will be the subject of a manuscript in preparation.

Acknowledgments The research leading to these results has received funding from the European Research Council under the European Union's Seventh Framework Program (FP7/2007-2013)/ ERC grant agreement 226144.

Open Access This article is distributed under the terms of the Creative Commons Attribution License which permits any use, distribution, and reproduction in any medium, provided the original author(s) and the source are credited.

\section{Appendix}

See Tables 1, 2 . 
Table 1 Abbreviations of domains and their coordinates including the areas depicted in Fig. 2 marking the ISM and WNPSM monsoon subsystems of the eastern Arabian Sea (ARA), Bay of Bengal (BEN), South China Sea (CHN), Philippine Sea (PHL) and their subregions

Area CIND refers to northwest India. The addition of prefixes $\mathrm{N}, \mathrm{S}$ or $\mathrm{E}$ defines the northern and southern subregions of the corresponding areas or their equatorward extension, respectively. Given the limited northward extension of the convective activity over the Philippine Sea beyond $15^{\circ} \mathrm{N}$, especially over its eastern parts, the northern subdomain of PHL is not included

\begin{tabular}{llcr}
\hline Area & Domain name & Lon range $\left({ }^{\circ} \mathrm{E}\right)$ & Lat range $\left({ }^{\circ} \mathrm{N}\right)$ \\
\hline EMED & & $17-31$ & $30-41$ \\
\hline Monsoon system & Subdomain & Lon range & Lat range \\
\hline ISM & ARA & $70-77$ & $5-22$ \\
& NARA & $70-77$ & $15-28$ \\
& SARA & $70-77$ & $5-15$ \\
& EARA & $70-77$ & $0-10$ \\
ISM & BEN & $82-100$ & $8-22$ \\
& NBEN & $82-100$ & $15-28$ \\
& SBEN & $82-100$ & $5-15$ \\
ISM & EBEN & $82-100$ & $0-10$ \\
WNPSM & CIND & $70-80$ & $15-28$ \\
& CHN & $110-120$ & $8-20$ \\
& NCHN & $100-120$ & $15-25$ \\
& SCHN & $100-120$ & $5-15$ \\
WNPSM & ECHN & $100-120$ & $0-10$ \\
& PHL & $125-150$ & $8-20$ \\
& SPHL & $125-150$ & $5-15$ \\
& EPHL & $125-150$ & $0-10$ \\
\hline
\end{tabular}

Table 2 List of abbreviations

\begin{tabular}{llll}
\hline Abbreviations & Explanations & Abbreviations & Explanations \\
\hline EMME & Eastern Mediterranean and the Middle East & BEN & Bay of Bengal \\
EMED & Eastern Mediterranean & NBEN & Northern BEN \\
JJAS & June-July-August-September & SBEN & Southern BEN \\
MSLP & Mean sea level pressure & EBEN & Equatorial extension of BEN \\
ISM & Indian summer monsoon & CHN & South China Sea \\
EASM & East Asian summer monsoon & NCHN & Northern CHN \\
WNPSM & Western North Pacific summer monsoon & SCHN & Southern CHN \\
ARA & Eastern Arabian Sea & ECHN & Southern extension CHN \\
NARA & Northern ARA & PHL & Philippines Sea \\
SARA & Southern ARA & SPHL & Southern PHL \\
EARA & Equatorial extension of ARA & EPHL & Equatorial extension of PHL \\
CIND & Core (continental) India & PVU & Potential vorticity unit \\
LTT & Local temperature tendency & TPTT & Total physics temperature tendency \\
VATT & Vertical advection temperature tendency & HATT & Horizontal advection temperature tendency \\
MATT & Meridional advection temperature tendency & ZATT & Zonal advection temperature tendency \\
\hline
\end{tabular}

\section{References}

Alpert P, Osetinsky I, Ziv B, Shafir H (2004) A new seasons definition based on classified daily synoptic systems: an example for the eastern Mediterranean. Int J Climatol 24:1013-1021

Bitan A, Saaroni H (1992) The horizontal and vertical extension of the Persian Gulf pressure trough. Int J Climatol 12:733-747

Charney JG (1975) Dynamics of deserts and drought in the Sahel. Q J R Meteorol Soc 101:193-202

Chronis T, Papadopoulos V, Nikolopoulos EI (2011) QuickSCAT observations of extreme wind events over the Mediterranean and Black Seas during 2000-2008. Int J Climatol 31:2068-2077
Ding Q, Wang B (2005) Circumglobal teleconnection in the Northern Hemisphere summer. J Clim 18:3483-3505

Ding Q, Wang B (2007) Intraseasonal teleconnection between the summer Eurasian wave train and the Indian monsoon. J Clim 20:3751-3767

Ding Y (2007) The variability of the Asian summer monsoon. J Meteorol Soc Jpn 85B:21-54

Ding Y, Sikka DR (2006) Synoptic systems and weather. In: Wang B (eds) The Asian monsoon. Praxis Publishing Ltd, Chichester, p 781

Fueglistaler S, Legras B, Beljaars A, Morcrette JJ, Simmons A, Tompkins AM, Uppala S (2009) The diabatic heat budget of the 
upper troposphere and lower/mid stratosphere in ECMWF reanalyses. Q J R Meteorol Soc 135:21-37

Gill AE (1980) Some simple solutions for heat-induced tropical circulation. Q J R Meteorol Soc 106:447-462

Giorgi F (2006) Climate change hot-spots. Geophys Res Lett 33:L08707. doi:10.1029/2006GL025734

Goswami BN, Annamalai H, Krishnamurthy V (1999) A broad scale circulation index for the interannual variability of the Indian summer monsoon. Q J R Meteorol Soc 125:611-633

HMSO (1962) Weather in the Mediterranean I: general meteorology, 2nd edn. Her Majesty Stationery Office, London, p 362

Holton JR (1992) An introduction to dynamic meteorology, 3rd edn. Academic Press, London

Hoskins BJ (1991) Towards a PV-theta view of the general circulation. Tellus 43:27-35

Hoskins BJ (1997) A potential vorticity view of synoptic development. Meteorol Appl 4:325-334

Hoskins BJ, McIntyre ME, Robertson AW (1985) On the use and significance of isentropic potential vorticity maps. Q J R Meteorol Soc 111:877-946

Joseph PV, Srinivasan J (1999) Rossby waves in May and the Indian summer monsoon rainfall. Tellus 51:854-864

Jung T, Ferranti L, Tompkins AM (2006) Response to the summer of 2003 Mediterranean SST anomalies over Europe and Africa. J Clim 19:5439-5454

Kalabokas PD, Mihalopoulos N, Ellul R, Kleanthous S, Repapis CC (2008) An investigation of the meteorological and photochemical factors influencing the background rural and marine surface ozone levels in the central and eastern Mediterranean. Atmos Environ 42:7894-7906

Lelieveld J, Berresheim H, Borrmann S et al (2002) Global air pollution crossroads over the Mediterranean. Science 298: 794-799

Lelieveld J, Hadjinicolaou P, Kostopoulou E, Chenoweth J, Giannakopoulos C, Hannides C, Lange MA, El Maayar M, Tanarthe M, Tyrlis E, Xoplaki E (2012) Climate change and impacts in the eastern Mediterranean and the Middle East. Clim Chang 114:667-687. doi: 10.1007/s10584-012-0418-4

Lin $\mathrm{H}$ (2009) Global extratropical response to diabatic heating variability of the Asian summer monsoon. J Atmos Sci 66: 2697-2713

Lin H, Derome J, Brunet $\mathrm{G}$ (2007) The nonlinear transient atmospheric response to tropical forcing. J Clim 20:5642-5665

Maheras P (1980) Le probleme des Etesiens. Mediterranee 40:57-66

Metaxas DA (1977) The interannual variability of the Etesian frequency as a response of atmospheric circulation anomalies. Bull Hell Meteorol Soc 2(5):30-40

Pai DS, Nair RM (2009) Summer monsoon onset over Kerala: new definition and prediction. J Earth Syst Sci 118:123-135

Parthasarathy B, Kumar RR, Kothawale DR (1992) Indian summer monsoon rainfall indices, 1871-1990. Meteor Mag 121:174-186

Parthasarathy B, Munot AA, Kothawale DR (1994) All India monthly and seasonal rainfall series: 1871-1993. Theor Appl Climatol 49:217-224

Prezerakos NG (1984) Does the extension of the Azores' anticyclone towards the Balkans really exist. Arch Meteorol Geophys Bioclimatol Ser A 33:217-227

Raicich F, Pinardi N, Navarra A (2003) Teleconnections between Indian monsoon and Sahel rainfall and the Mediterranean. Int J Climatol 23:173-186
Reddaway JM, Bigg GR (1996) Climatic change over the Mediterranean and links to the more general atmospheric circulation. Int J Climatol 16:651-661

Rodwell MJ, Hoskins BJ (1996) Monsoons and the dynamics of deserts. Q J R Meteorol Soc 122:1385-1404

Rodwell MJ, Hoskins BJ (2001) Subtropical anticyclones and summer monsoons. J Clim 14:3192-3211

Rowell DP (2003) The impact of Mediterranean SSTs on the Sahelian rainfall season. J Clim 16:849-862

Saaroni H, Ziv B (2000) Summer rain episodes in a Mediterranean climate, the case of Israel: climatological-dynamical analysis. Int J Climatol 20:191-209

Saaroni H, Ziv B, Osetinsky I, Alpert P (2010) Factors governing the interannual variation and the long-term trend of the $850 \mathrm{hPa}$ temperature over Israel. Q J R Meteorol Soc 136:305-318

Schulman LL (1973) On the summer hemisphere Hadley cell. Q J R Meteorol Soc 99:197-201

Sciare J, Bardouki H, Moulin C, Mihalopoulos N (2003) Aerosol sources and their contribution to the chemical composition of aerosols in the eastern Mediterranean Sea during summertime. Atmos Chem Phys 3(1):291-302

Traub M, Lelieveld J (2003) Cross-tropopause transport over the eastern Mediterranean. Journal of Geophysical Research 180:4712. doi:10.1029/2003JD003754

Trenberth KE, Hurrel JW, Stepaniak DP (2006) The Asian monsoon: global perspectives. In: Wang B (eds) The Asian monsoon. Praxis Publishing Ltd, Chichester, p 781

Uppala SM, Kallberg PW, Simmons AJ et al (2005) The ERA-40 Reanalysis. Q J R Meteorol Soc 131:2961-3012

Wang B (1994) Climatic regimes of tropical convection and rainfall. J Clim 7:1109-1118

Wang B, Fan Z (1999) Choice of South Asian summer monsoon indices. Bull Am Meteorol Soc 80:629-638

Wang B, LinHo (2002) Rainy season of the Asian-Pacific summer monsoon. J Clim 15:386-398

Wang B, Wu R, Lau KM (2001) Interannual variability of the Asian summer monsoon: contrasts between the Indian and the Western North Pacific-East Asian monsoons. J Clim 14:4073-4090

Wang B, Ding Q, Joseph PV (2009) Objective definition of the Indian summer monsoon onset. J Clim 22:3303-3316

Webster PJ (1994) The role of hydrological processes in oceanatmosphere interactions. Rev Geophys 32(4):427-476

Webster PJ, Yang S (1992) Monsoon and ENSO: selectively interactive systems. Q J R Meteorol Soc 118:877-926

Yang S, Lu WKM (2006) Interannual variability of the Asian monsoon. In: Wang B (eds) The Asian monsoon. Praxis Publishing Ltd, Chichester, p 781

Zarrin A, Ghaemi H, Azadi M, Farajzadeh M (2010) The spatial pattern of summertime subtropical anticyclones over Asia and Africa: a climatological review. Int J Climatol 30:159-173

Zecchetto S, de Biasio F (2007) Sea surface winds over the Mediterranean basin from satellite data (2000-04): meso- and local-scale features on annual and seasonal time scales. J Appl Meteorol Climatol 46:814-827

Zhang Y, Li T, Wang B, Wu G (2002) Onset of the summer monsoon over the Indochina Peninsula: climatology and interannual variations. J Clim 15:3206-3221

Ziv B, Saaroni H, Alpert P (2004) The factors governing the summer regime of the eastern Mediterranean. Int $\mathrm{J}$ Climatol 24: $1859-1871$ 